From brawn to brains: manufacturing-KIBS interdependency

Dioni Elche, Davide Consoli, Mabel Sánchez-Barrioluengo

Working Paper N²017-01 


\title{
From brawn to brains: manufacturing-KIBS interdependency
}

Dioni Elche ${ }^{1, a}$, Davide Consoli ${ }^{2, b}$, Mabel Sánchez-Barriolueng ${ }^{3, c}$

\author{
${ }^{1}$ Universidad de Castilla-La Mancha, Facultad de Ciencias Sociales \\ ${ }^{2}$ INGENIO, CSIC-Universitat Politècnica de València (Spain) \\ ${ }^{3}$ European Commission. Joint Research Centre. Directorate Growth \& Innovation. Unit \\ of Human Capital and Employment
}

a dioni.elche@uclm.es

${ }^{\mathrm{b}}$ davide.consoli@ingenio.upv.es

${ }^{\mathrm{c}}$ Mabel.Sanchez-Barrioluengo@ec.europa.eu 


\section{Table of Contents}

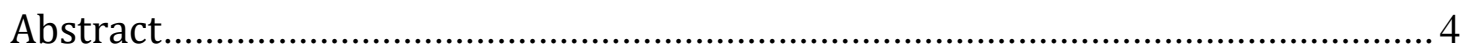

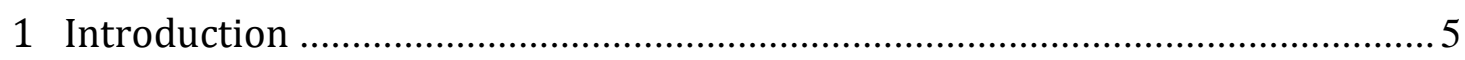

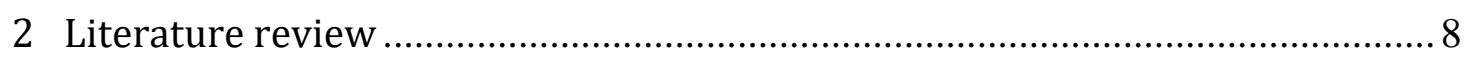

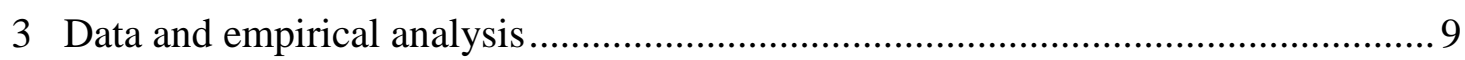

3.1. Data Sources and variable construction.............................................. 10

3.2. Empirical background and descriptive statistics................................ 15

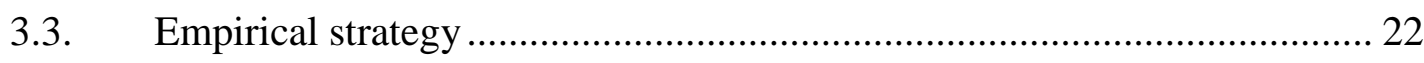

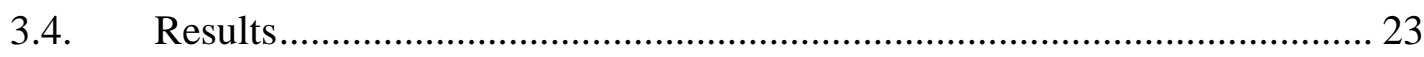

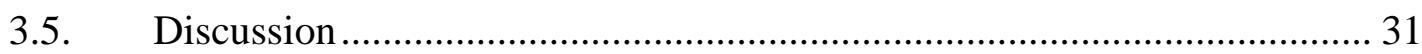

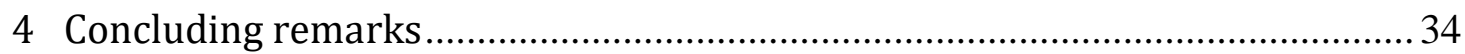

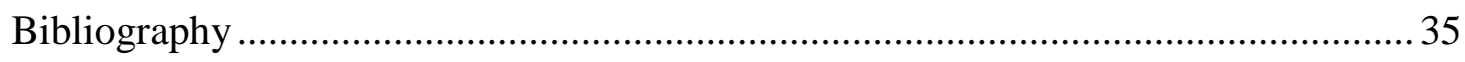

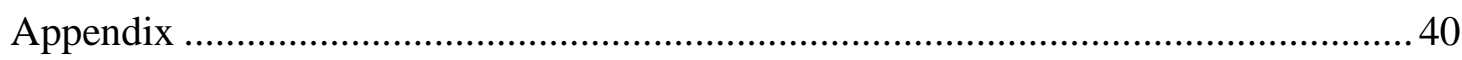




\begin{abstract}
This paper analyses the interdependency between manufacturing and KIBS by focussing on two questions: which manufacturing industries are complementary with KIBS development? And, do cross-sectoral interdependencies exhibit geographical heterogeneity? We elaborate an empirical analysis of employment data of 279 municipalities in Spain over the period 1981-2011. Our first finding is that the typology of manufacturing activities that have positive employment effect ranges between two opposite poles: either well-established (viz. supplier-dominated) or emergent (viz. science based) industries. Further, and coherent with prior literature, we find that the overall job multiplier effect of manufacturing on KIBS is most prominent in areas with denser agglomeration.
\end{abstract}

Keywords: Knowledge Intensive Business Services; Manufacturing; Employment; Job Multiplier. 


\section{Introduction}

Knowledge Intensive Business Services (KIBS) are suppliers of consultancy activities such as screening, assessment and evaluation. The label KIBS, coined by Miles et al. (1995), powerfully synthesises the nexus between the input, knowledge, and the tradable output, information, that stands at the core of these activities. KIBS have captured the interest of scholars and policy makers alike for a number of reasons. First, the sectors in which business services operate have acquired economic significance, both in terms of the absorbed workforce and of the value added that is generated (Kox and Rubalcaba, 2007). Second, KIBS are widely appraised as innovation enablers due to their capacity to promote variety through inter-sectoral linkages (i.e. Boden and Miles 2000; Kuusisto and Meyer 2003; Ciriaci et al, 2015; Meliciani and Savona, 2014). Further, studies in economic geography emphasise the pivotal role of KIBS in the development of local innovation systems, both at the city and the regional levels (i.e. Wood et al, 1993; Strambach, 2008; Cooke and Leydesdorff, 2006; Corrocher and Cusmano, 2014). Fourth, the promotion of business services is touted as an effective policy lever for countering the decline of industries or for managing uncertainty in the pursuit of new market opportunities (Den Hertog, 2000; Muller \& Zenker, 2001; Koch and Stahlecker, 2006).

While most of the existing literature aims at characterising or measuring the innovation outcomes associated to KIBS, the circumstances underlying their emergence have rarely been scrutinised. The established belief is that KIBS develop as a response to growing demand for specialised knowledge arising in the manufacturing industry. This is a trademark assumption on the evolution of capitalism whereby firms operating in mature industries may confront challenges due to the appearance either of new competitors or of unexplored market opportunities. In this context, developing routines of knowledge production and use is essential to pursue, maintain or restore the competitive edge (Pavitt, 2002; Ciarli et al. 2012; Metcalfe, 2014). KIBS do just that: they complement manufacturing activities by making available knowledge inputs that would be otherwise too costly or out of the cognitive range. While much has been said about their effects on other sectors or on the local economy, there little evidence - Corrocher and Cusmano (2014) and Meliciani and Savona (2014) being the exceptions - on the cross-sectoral interdependencies underpinning the growth and development of KIBS. Such a gap 
motivates the following research questions:

1) Which manufacturing industries are complementary with KIBS development? Addressing this question entails a full account of cross-sectoral heterogeneity in manufacturing-KIBS interdependencies.

2) Do cross-sectoral interdependencies exhibit geographical heterogeneity? The expectation is that KIBS will locate in cities with higher density of potentially related activities and of human capital. We propose to investigate combined sectoral and spatial characteristics of manufacturing-KIBS connections.

These issues are explored through an empirical analysis of employment data of 399 municipalities in Spain over the period 1981-2011. This empirical context offers an attractive backdrop for a number of reasons. Industrialization in Spain took off in the early 1960s, after decades of autarky and later compared to other Western European countries, propelled through the 1970s by strategic plans that mandated the creation of state-owned enterprises in strategic sectors and strategic locations. Our analysis coincides with the period that followed on these premises, and that saw profound institutional, economic and social transformations punctuated by milestones such as the devolution of competences to regions, labour market reforms, the accession to the European Community as well as policy interventions that have sought to rejuvenate the industry mix, probably with a mixed record. Between 1981 and 2011 the Spanish economy has gone through it all, from early industrialization, to de-industrialization and, more recently, re-industrialization, not to mention phases of booming growth and of deep recession. Against this backdrop, KIBS have gone from being negligible to absorbing as much as $20 \%$ of the overall workforce.

Our analysis of the interdependencies between manufacturing and KIBS focuses on the intuition that changes in employment affect an area's entire spectrum of activities. Accordingly, we apply an empirical strategy that measures the local job multiplier effect, that is, complementary changes in the workforce of manufacturing and of KIBS. Prior studies employing this technique (see Bartik, 1991; Moretti, 2010; Black et al, 2005; Moretti and Thulin, 2013; Marchand, 2012; Faggio and Overman, 2014; van Dijk, 2017) focus primarily on the job multiplier effect on local non-tradable activities that employ low-skill/low-pay workers such as cleaning services, grocery stores et cetera. However also KIBS exhibit a strong local character due to the importance of client-customer interaction and the necessarily contextual nature of expertise that is needed to provide 
business services. To the best of our knowledge, this is the first paper to analyse the job creation effect in high-skill activities like knowledge intensive business services.

We employ OLS and IV estimates to assess the local employment effect of manufacturing industries on KIBS. To address the first research question we run benchmark regressions for all KIBS sectors and all municipalities pooled together and find that the job multiplier is 9.2 new KIBS jobs for each manufacturing job. Looking at individual industries, the effect is polarised between mid-skill 'supplier dominated' (see Pavitt, 1984) industries wood \& furniture (0.6 new KIBS jobs) and leather \& footwear (0.2) - and high-skill 'science based' (ibid.) hi-tech manufacturing (0.1). None of the remaining seven finer digit manufacturing industries have a significant effect. This pattern of interdependency does not change when we run separate regressions to distinguish between financial and nonfinancial KIBS sectors (see Brenner et al, 2017), although the job multiplier for the latter is higher relative to financial KIBS.

To address the second research question we replicate the above empirical strategy by separating municipalities by population density. Coherent with the indications of prior literature, the overall job multiplier effect of manufacturing on KIBS is mostly concentrated in denser municipalities. Compared to the benchmark estimates above (all KIBS sectors and all areas are pooled together) these results confirm the finding of industry polarisation, the only difference being that in denser areas the other 'science based' industry, plastic \& chemicals has a significant employment effect ( 0.3 new KIBS jobs). In sparser municipalities the job multiplier effect is limited to leather \& footwear (0.2). When financial and non-financial KIBS are taken separately, significant effects are only observed in denser municipalities, and the pattern of interdependency differs. For financial KIBS the job multiplier is polarised between leather \& footwear $(0.2)$ and hi-tech (0.2) while the main drivers of employment growth for non-financial KIBS are plastic \& chemicals (0.9), wood \& furniture (1.3) and, again, leather \& footwear (0.3).

The remainder of the paper is organised as follows. After a review of the relevant literature in Section 2, we outline in Section 3 the description of the data and the empirical analysis. The last section summarises and concludes. 


\section{Literature review}

KIBS are suppliers of intermediate inputs that draw on technical expertise and are traded in the form of information (Miles et al. 1995). KIBS are problem-solvers that offer assistance in a wide range of forms to other businesses, mainly locating, developing, combining, and adapting generic knowledge to specific issues. A burgeoning stream of scholarly work praises the capacity of KIBS to generate learning opportunities, to favour the creation and consolidation of inter-sectoral linkages and to enhance connectivity outside the boundaries of established knowledge networks (i.e. Wood et al, 1993; Strambach, 1998; Den Hertog, 2000; Tether and Hipp, 2002; Miles, 2005; Muller and Doloreux, 2009). This upsurge of scholarly interest has gone hand in hand with the remarkable growth of KIBS across most advanced economies, as evidenced by rising number of firms, of shares of workforce and of value added (Kox and Rubalcaba, 2007).

A question remains, however, understudied: where do KIBS come from? While the literature focuses on the characteristics and/or the performance of this class of service activities, very few have inquired into the circumstances that germinate the development of KIBS. This bears relevance because, in spite of early literature suggesting otherwise, there is growing consensus on the inherent diversity of business services across sectors, geographical areas and pathways of knowledge flows (Tether and Hipp, 2002; Freel, 2006; Von Nordenflycht, 2010; Malhotra and Morris, 2009; Consoli and Elche-Hortelano, 2010; Pina and Tether, 2016). By the same token, there is scope for further qualifying the nature and the role of interdependencies with pre-existing industrial activities that may favour or thwart the development of KIBS. To clarify, we are not invoking the image of services as subordinate to manufacturing that was common in earlier literature (i.e. Pavitt, 1984) but, rather, seeking to operationalise the argument that specialisation and diversification are two different sides of the same coin. The present paper is grounded in the tenet that when industries achieve a degree of maturity, specialist knowledge providers like KIBS provide opportunities for increasing efficiency in the existing competitive setting but, also, for pursuing new business opportunities - for example, the expansion of product lines or access to new markets (Pavitt, 2002; Ciarli et al. 2012; Metcalfe, 2014). Put otherwise, KIBS complement manufacturing activities by making available knowledge inputs that would be otherwise too costly or out of the cognitive range.

In searching for the genesis of KIBS, we ought to acknowledge the space-bound nature of 
sectoral interdependency. Regionalists argue that as local economies develop, the demand for knowledge inputs becomes more sophisticated and the role of private specialized providers becomes more prominent. Indeed, KIBS play a strategic role in more dynamic regions where advanced manufacturing relies on intensive knowledge feedback (Muller and Zenker, 2001). By the same token, KIBS tend to be located in cities where opportunities for knowledge spillovers are higher due to proximity to related activities, to better access to infrastructures or to the effects of higher density, for example labour market pooling (Wood et al., 1993; Fujita and Tabuchi, 1997; Kolko, 1999; Shilton and Stanley, 1999; Simmie and Strambach, 2006; Aslesen and Jakobsen, 2007; Shearmur and Doloreux, 2009; Antonietti et al, 2013; Herstad and Ebersberger, 2014; Jacobs et al, 2014). Urban economists go further and ascribe to the expansion of business services in cities the transition from narrow sectoral specialization to functional specialization in multi-purpose activities, such as management (Henderson, 1988; Kolko, 2010; Duranton and Puga, 2004).

The connection between KIBS and the broader regional economy has been analysed through various empirical dimensions, such as regional growth patterns (Corrocher and Cusmano, 2014), intersectoral linkages (Meliciani and Savona, 2014), firms' knowledge bases (Pina and Tether, 2016), and employment growth (Brenner et al, 2017). By and large, these studies share the view that the characteristics of manufacturing sectors shape the development of KIBS, and that the quality of the connections between the two domains are crucial for regional performance. At the same time, scholars concur that the variety of regional patterns in manufacturing and KIBS co-evolution calls for further analysis (Corrocher and Cusmano, 2014), and that research should assess how different typologies of KIBS and manufacturing segments interact (Brenner et al, 2017). The present paper takes the cue from both these remarks and our earlier comment that, bar few exceptions, the role of local industry structure in the genesis of KIBS has been neglected. The next section will address these issues.

\section{Data and empirical analysis}

This section is organised in four parts. After having detailed the data sources and the construction of the main variables in the first subsection, the second contains descriptive statistics and initial insights into the magnitude, temporal and spatial distribution of 
manufacturing industries and KIBS in Spain. The third subsection outlines the empirical strategy that is implemented in the fourth and last part.

\subsection{Data Sources and variable construction}

Our study focuses on the interdependencies between employment in manufacturing and in KIBS sectors across Spanish municipalities over the period 1981-2011. ${ }^{4}$ The main data source is the decennial Population and Housing Census Survey (Census) ${ }^{5}$ from which we extract and aggregate information on individuals' residence and sector of employment at municipality-level. ${ }^{6}$ To calculate employment rates we select full- and part-time private sector employees and assign each observation to a municipality based on residence. ${ }^{7}$ Due to the privacy policy of Census, the analysis is restricted to municipalities with more than 20,000 inhabitants due to data availability. ${ }^{8}$ Our final sample includes 399 different municipalities (lower portion, Fig. 1) located in 50 provinces (upper portion, Fig. 1).

\footnotetext{
${ }^{4}$ The regions and municipalities of Ceuta y Melilla have been excluded from the analysis due to their peculiarities: these are two provinces home to autonomous cities in the North of Africa with lower administrative competences compared to other Spanish provinces.

${ }^{5}$ More information available at: http://www.ine.es/en/censos2011_datos/cen11_datos_inicio_en.htm

${ }^{6}$ Although the original source of information for this survey is the Spanish Statistical Office, the 1981 database is made available by iPUMS: https://www.ipums.org/

${ }^{7}$ We use the weighting factor provided by the Spanish national office of statistics. Since Census data for 1991 do not include such a factor, we applied a value of 20 for each individual following the iPUMS version of the same database for this year.

${ }^{8} \mathrm{We}$ only select municipalities for which information is available for at least three, out of four, years.
} 


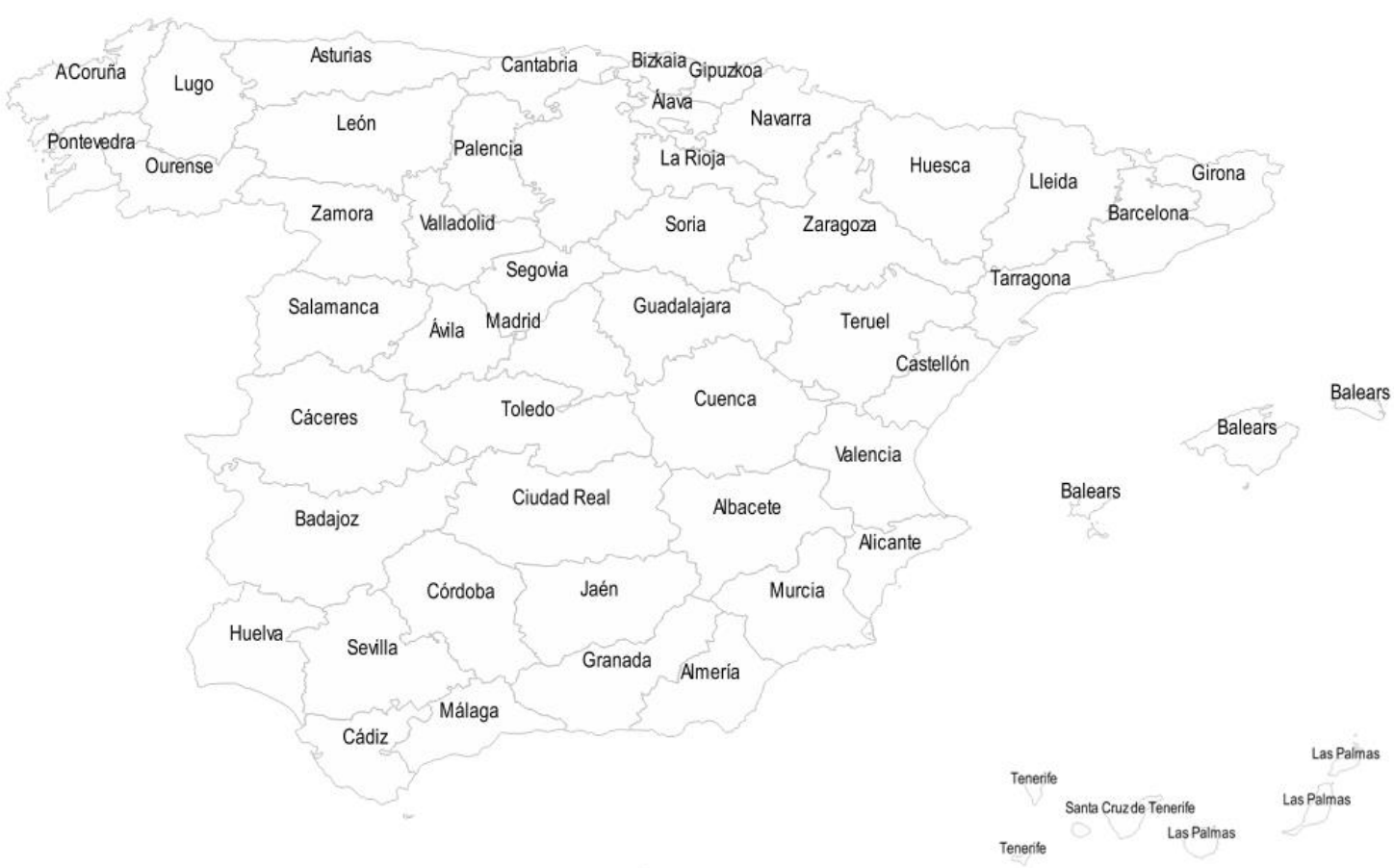

Provinces

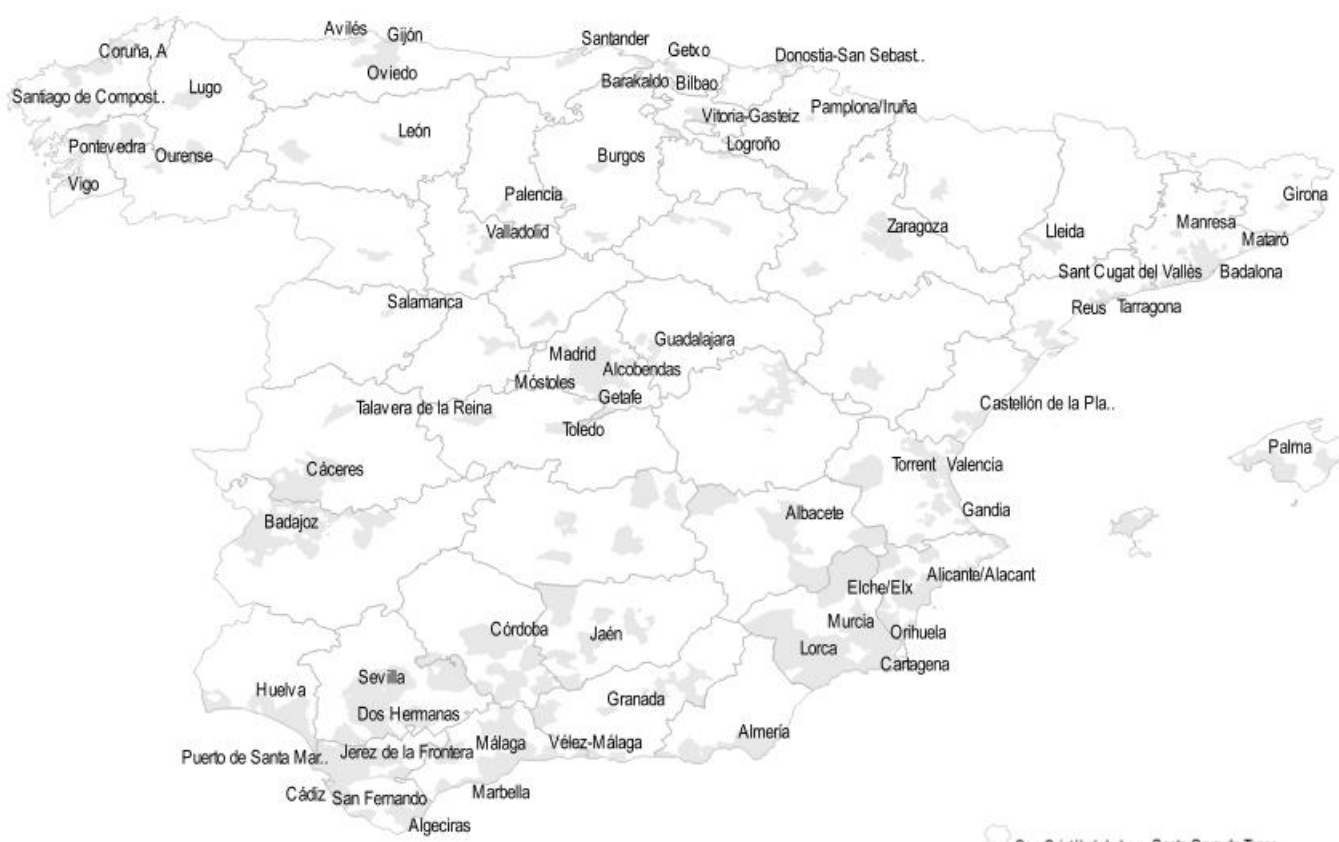

San Cristica de La. Sarta Craz de Tenec.

Paimas de Gran Cana.

Telde

Municipalities (population>100000)

Figure 1. Geography of Spain: provinces and municipalities 
The dependent variable is the difference between the logarithm (ln) of total employment in KIBS sectors between two consecutive decades. Following Brenner et al (2017) and the literature cited therein (p. 4) we initially focus on employment in all business services and subsequently consider financial KIBS and non-financial KIBS separately. ${ }^{9}$ The main explanatory variable is change in manufacturing employment, taken both in aggregate and in ten finer digit industries: Metal; Food \& Tobacco; Textile \& Clothing; Leather \& Footwear; Wood \& Furniture; Paper \& Editing; Plastic \& Chemical; Machinery; Transport Equipment; and Hi-Tech Manufacturing. ${ }^{10}$

We also include a battery of area-specific control variables to account for structural changes in the local economy over the three decades under analysis, specifically: collegenon-college ratio as a proxy of general level of education; local unemployment rate; share of entrepreneurs and percentage of immigrant workers. Table 1 contains the descriptive statistics of these variables while Table 2 shows the correlation matrix.

\footnotetext{
${ }^{9}$ NACE codes for KIBS are: 1981 (81-84) where 81-83 are finance; 1991 (23-24) where 23 is finance; 2001 (66-67,70-71,73-75) where 66-67 and 70 are finance; 2011 (64-66,68-74) where 64-66 and 68 are finance. ${ }^{10}$ NACE codes for manufacturing industry: 1) Metal: 1981 code 31; 1991 codes 11-12; 2001 codes 28-291; 2011 codes 24-25. 2) Food \& Tobacco: 1981 code 42; 1991 code 5; 2001 codes 16-17; 2011 codes 10-12. 3) Textile \& Clothing: 1981 code 43; 1991 code 6; 2001 codes 18-19; 2011 codes 13-14. 4) Leather \& Footwear: 1981 codes 44-45; 1991 code 15; 2001 code 20; 2011 codes 15 and 32. 5) Wood \& Furniture: 1981 code 43; 1991 code 7; 2001 codes 21 and 37; 2011 codes 16 and 31. 6) Paper \& Editing: 1981 code 47; 1991 code 8; 2001 codes 22-23; 2011 codes 17-18. 7) Plastic \& Chemical: 1981 codes 48-49; 1991 code 10; 2001 codes 25-27; 2011 codes 20-23. 8) Machinery: 1981 codes 32-35; 1991 code 18; 2001 codes 30-32 and 35; 2011 code 29. 9) Transport Equipment: 1981 codes 36-38; 1991 code 14; 2001 code 36; 2011 code 30. 10) HiTech Manufacturing: 1981 code 39; 1991 code 13; 2001 codes 33-34; 2011 codes 26-28.
} 


\begin{tabular}{l|ccccc}
\hline \multicolumn{1}{c|}{ Variable } & Obs & Mean & $\begin{array}{c}\text { Std. } \\
\text { Dev. }\end{array}$ & Min & Max \\
\hline Employment KIBS & 789 & 0.531 & 0.966 & -1.561 & 3.434 \\
Employment KIBS finance & 771 & 0.502 & 1.145 & -2.927 & 3.866 \\
Employment KIBS non-finance & 749 & 0.562 & 1.894 & -3.809 & 5.085 \\
Total manufacturing & 793 & -0.035 & 0.478 & -1.605 & 2.358 \\
Metal & 777 & -0.003 & 0.781 & -2.845 & 2.647 \\
Food \& Tobacco & 622 & 0.027 & 1.754 & -4.752 & 3.897 \\
Textile \& Clothing & 673 & -0.072 & 1.164 & -3.707 & 5.659 \\
Leather \& Footwear & 652 & -0.292 & 1.417 & -4.939 & 4.173 \\
Wood \& Furniture & 587 & -0.201 & 1.057 & -3.786 & 4.947 \\
Papers \& Editing & 689 & 0.046 & 0.782 & -3.499 & 3.558 \\
Plastic \& Chemical & 721 & 0.285 & 1.093 & -3.159 & 4.817 \\
Machinery & 636 & -0.223 & 1.344 & -3.922 & 3.954 \\
Transport Equipment & 594 & -0.330 & 1.440 & -5.919 & 4.748 \\
Hi-Tech & 797 & 17.816 & 6.303 & 5.894 & 33.743 \\
Immigrants (\%) & 519 & 0.513 & 1.391 & -4.235 & 4.650 \\
Colleges (\%) & 763 & 0.021 & 0.035 & 0.000 & 0.360 \\
Entrepreneurs (\%) & 797 & 11.716 & 6.631 & 1.559 & 51.383 \\
Unemployment (\%) & 797 & 5.818 & 2.209 & 1.640 & 28.103 \\
\hline & & & & & \\
\hline
\end{tabular}




\begin{tabular}{|c|c|c|c|c|c|c|c|c|c|c|c|c|c|c|c|c|c|}
\hline & 1 & 2 & 3 & 4 & 5 & 6 & 7 & 8 & 9 & 10 & 11 & 12 & 13 & 14 & 15 & 16 & 17 \\
\hline Employment KIBS & 1 & & & & & & & & & & & & & & & & \\
\hline Employment KIBS finance & $-0.617^{* \star *}$ & 1 & & & & & & & & & & & & & & & \\
\hline Employment KIBS non-finance & $0.929^{* * *}$ & $-0.814^{\star \star *}$ & 1 & & & & & & & & & & & & & & \\
\hline Total manufacturing & $-0.158^{* * *}$ & 0.050 & $-0.067^{*}$ & & & & & & & & & & & & & & \\
\hline Metal & $0.346^{* * *}$ & $-0.425^{\star * *}$ & $0.463^{* \star *}$ & & & & & & & & & & & & & & \\
\hline Food \& Tobacco & $-0.732^{* \star *}$ & $0.697^{* \star *}$ & $-0.754^{\star \star \star}$ & & & & & & & & & & & & & & \\
\hline Textile \& Clothing & -0.020 & -0.041 & $0.072^{*}$ & & & & & & & & & & & & & & \\
\hline Leather \& Footwear & 0.016 & 0.030 & 0.030 & & & & & & & & & & & & & & \\
\hline Wood \& Furniture & $-0.336^{* \star *}$ & $0.437^{* * *}$ & $-0.442^{* \star *}$ & & & & & & & & & & & & & & \\
\hline Papers \& Editing & $0.264^{* * *}$ & $-0.232^{* \star *}$ & $0.293^{* * *}$ & & & & & & & & & & & & & & \\
\hline Plastic \& Chemical & 0.042 & $-0.112^{\star * \star}$ & $0.127^{\star \star *}$ & & & & & & & & & & & & & & \\
\hline Machinery & $-0.159^{* \star *}$ & $0.121^{* * *}$ & $-0.109^{\star * \star}$ & & & & & & & & & & & & & & \\
\hline Transport Equipment & $0.293^{* * *}$ & $-0.385^{\star \star *}$ & $0.375^{* \star *}$ & & & & & & & & & & & & & & \\
\hline Hi-Tech & $0.132^{* * *}$ & $-0.163^{\star \star *}$ & $0.217^{* * *}$ & & & & & & & & & & & & & & \\
\hline Immigrants (\%) & $-0.202^{\star \star *}$ & $0.318^{* * *}$ & $-0.289^{* \star *}$ & 0.039 & $-0.242^{* * *}$ & $0.205^{\star \star *}$ & $-0.121^{* * *}$ & 0.045 & $0.268^{* * *}$ & 0.020 & $-0.106^{* \star *}$ & $-0.075^{\star}$ & $-0.174^{* \star *}$ & $-0.138^{\star * *}$ & 1 & & \\
\hline Colleges (\%) & $-0.212^{\star \star *}$ & $0.203^{* \star *}$ & $-0.222^{\star \star \star}$ & $-0.092^{* * *}$ & $-0.162^{* * *}$ & $0.179^{\star \star \star}$ & $-0.066^{*}$ & 0.026 & $0.185^{* \star *}$ & $-0.173^{\star \star *}$ & -0.027 & -0.061 & $-0.119^{* \star *}$ & $-0.114^{\star * *}$ & $0.075^{\star \star}$ & 1 & \\
\hline Entrepreneurs (\%) & $0.131^{* * *}$ & $-0.086^{* *}$ & $0.094^{* *}$ & $-0.163^{* * *}$ & -0.051 & $-0.119^{\star * *}$ & $-0.170^{* * *}$ & -0.044 & $0.137^{* * *}$ & -0.011 & $-0.174^{* * *}$ & $-0.216^{* * *}$ & $0.097^{* *}$ & $-0.186^{* * *}$ & $0.235^{* * *}$ & $0.065^{*}$ & 1 \\
\hline Unemployment (\%) & $0.360^{\star * \star}$ & $-0.291^{* \star *}$ & $0.355^{\star \star \star}$ & -0.008 & $0.253^{\star * \star}$ & $-0.295^{\star \star *}$ & 0.043 & 0.051 & $-0.183^{\star \star *}$ & $0.124^{* * *}$ & 0.031 & $-0.141^{* * *}$ & $0.299^{\star * *}$ & 0.072 & $-0.115^{* \star *}$ & $-0.200^{\star * \star}$ & $-0.188^{\star * \star}$ \\
\hline
\end{tabular}

Table 2. Correlation matrix 


\subsection{Empirical background and descriptive statistics}

The structural changes in the sectoral composition of the Spanish economy provide a first empirical motivation to the present paper. Figure 2 contains an overview of changes in employment shares across macro sectors: primary, construction and utilities, trade and transport, manufacturing, KIBS and other services. In the three decades between 1981 and 2011, manufacturing industries lost their dominance with a fall in share of employed workforce from $35 \%$ to $11 \%$. The decline has been sharpest in the transition between 1991 and 2001, against the background of the recessionary phase between 1993 and 1996 due to falling domestic demand and growing foreign competition. Scholars argue that this period marks the beginning of de-industrialization and the deepening of differences in economic performance across regions (Perez et al, 2006; Prados de la Escosura, 2017). The other significant shift is the rise of service activities which, combined all together, account in 2011 for about $68 \%$ of employment. Among these, low-skill service activities hold the lion share owing to impressive acceleration since the early 1990s. The other notable feature is the expansion of KIBS, which more than doubled (from $8.5 \%$ to $19 \%$ employment share) in the period under analysis. These two major shifts have been accompanied by other adjustments over the three decades: primary activities, initially the third largest industry, experienced a decline from $15 \%$ to less than $5 \%$, while Trade \& Transport, Construction and Utilities enjoyed moderate growth.

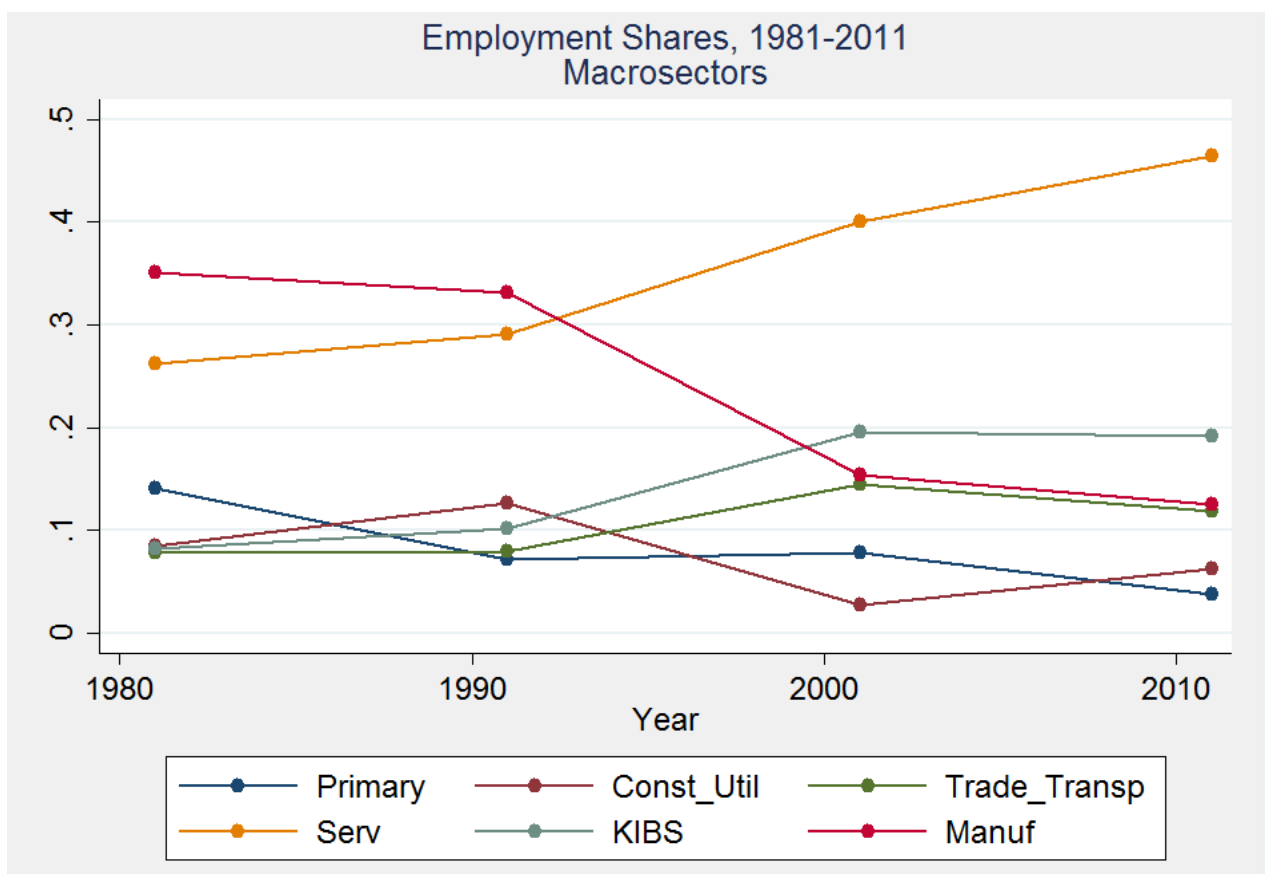

Figure 2. Shares of employment by major industry groups in Spain (1981-2011) 
Beneath the aggregate level, the trends of Figure 3 indicate that the crisis of the mid-1990s marked the onset of a decline in manufacturing. The figure also reveals that after 2001 structural changes took place, especially evident in the acceleration of production of plastic $\&$ chemicals, food \& tobacco, wood \& furniture and leather \& footwear. Scholarly studies on the long-term evolution of the Spanish economy concur that underlying these structural changes in sectoral shares is a process of spatial redistribution. Following the recession of the 1990s, the provinces that are home to the largest cities reoriented their productive bases. Thus, Madrid continued to enjoy its status of capital city to attract high-end business services for telecommunications, transport, energy and banking. Catalonia embarked on a slow reconversion of its industrial capacity from textiles to automobiles and chemicals. The region of Valencia became a seedbed of medium-tech manufacturing activities such as toys, ceramics, furniture, shoes. Formerly depressed regions such as Aragon, Rioja and Navarra experienced industrial expansion due to lower costs and improved transport infrastructures while the traditional strongholds of heavy industry - i.e. ship building, metal production and mining - in the north - Castile-Leon, Cantabria and the Basque Country entered in decline (Buesa and Molero, 1998; Garrido, 2002).

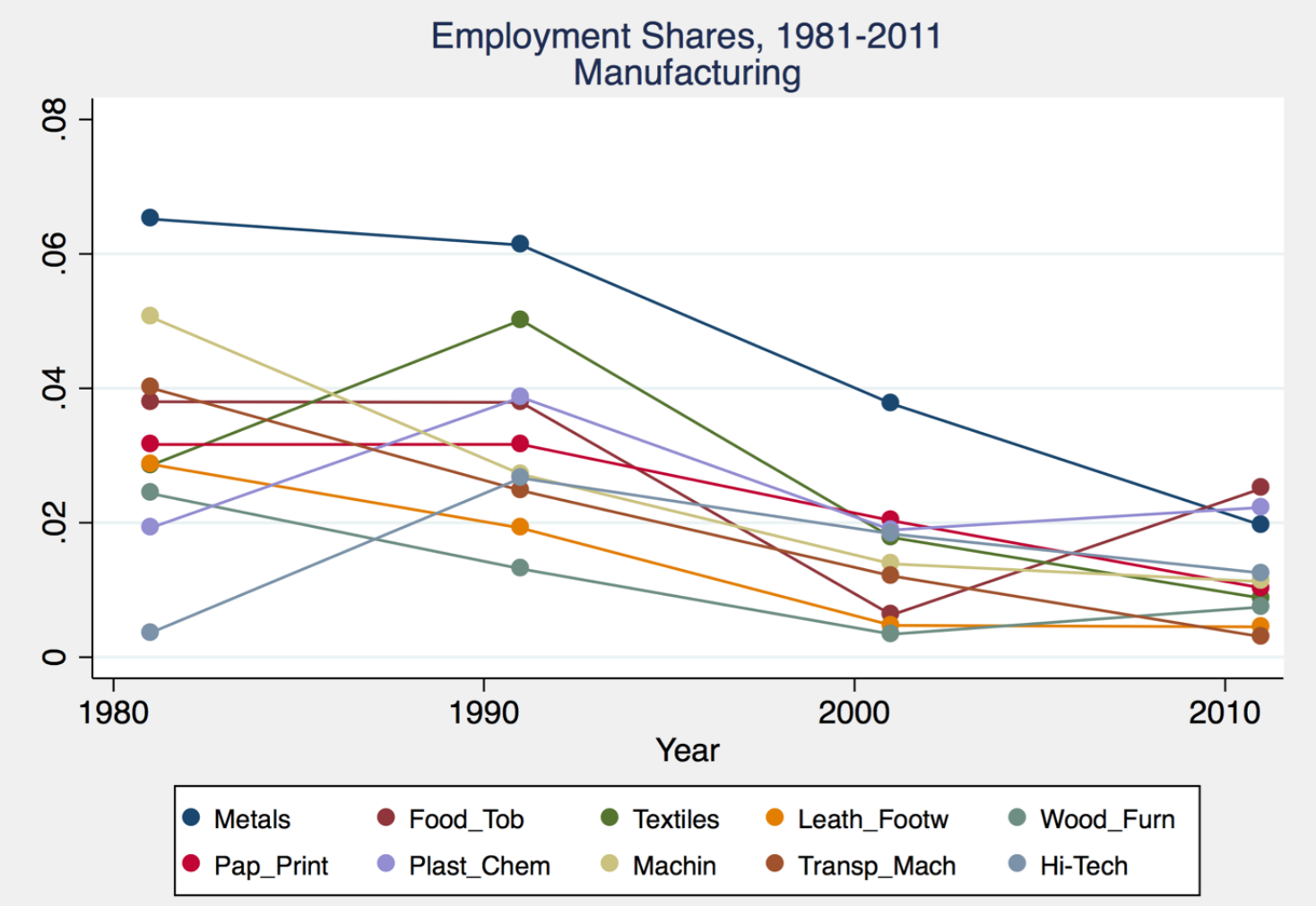

Figure 3. Shares of employment in Manufacturing industries (1981-2011) 
Turning to KIBS, Figure 4 indicates that the share of employment increased around $40 \%$ between 1981 and 2011, and that the acceleration took place in the 1990s. At the same time, important differences emerge when looking at financial and non-financial KIBS separately. While during the 1980 s both experienced employment growth $(21.8 \%$ for financial KIBS and $64.7 \%$ for non-financial KIBS) during the 1990s and 2000s the two trends moved in opposite directions. Financial KIBS employment fell mildly to about $2.5 \%$ between 1991 and 2001 but resurged to almost 15\% by the end of the following decade. On the contrary, non-financial KIBS jobs grew fast during the second decade to undergo, after the peak of 2000 (17\%) considerable decline by the end of the period (less than 5\% in 2011). This pattern resonates with the widely documented boom and bust of the construction sector and the collateral role of financial activities in Spain (i.e. Prado de la Escosura, 2017).

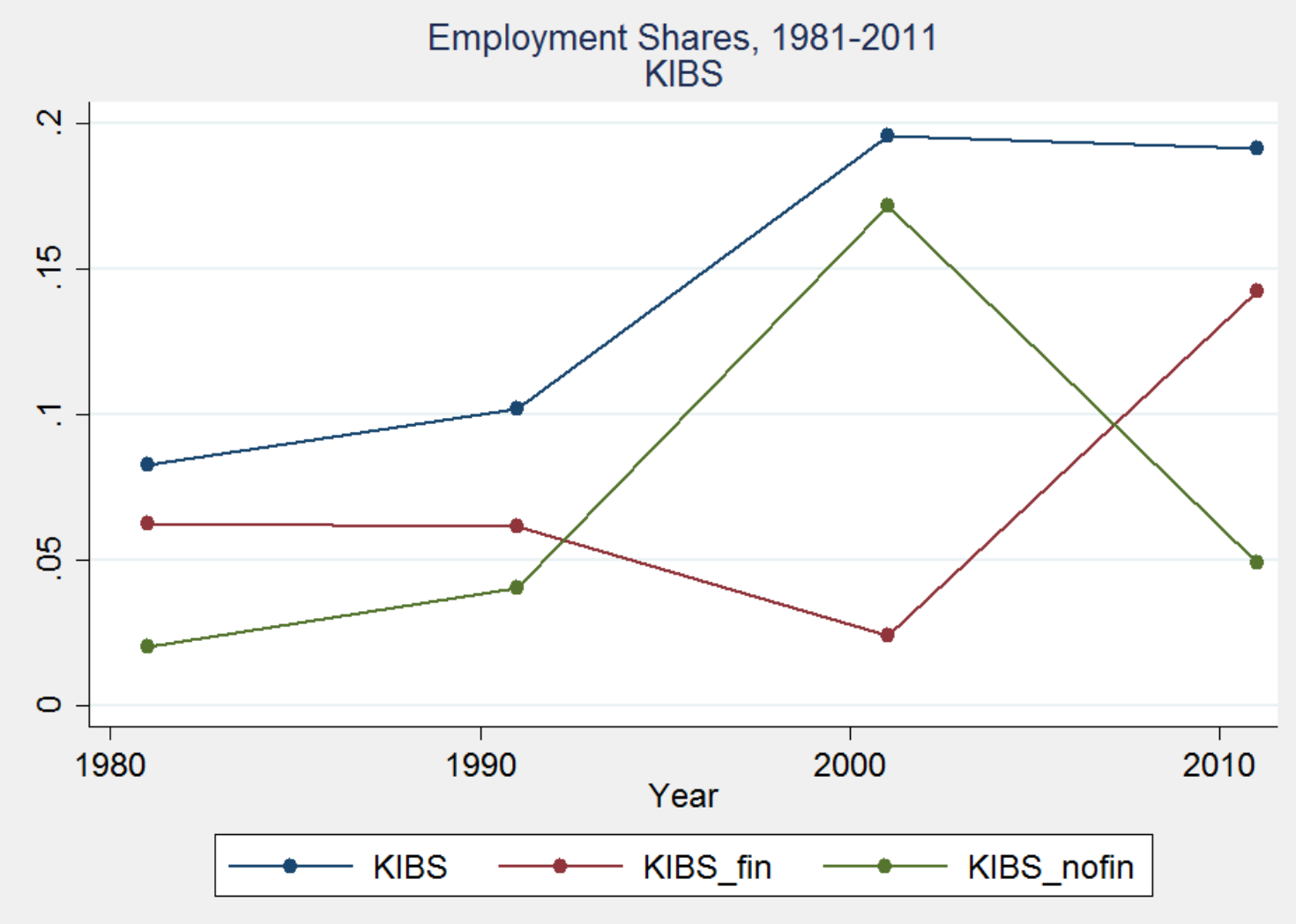

Figure 4. Shares of employment in financial and non-financial KIBS (1981-2011) 
These shifts in the composition of employment speak to the structural transformations of the context at hand, and of why it is of interest for the purposes of our analysis. A latecomer among industrialised countries, Spain has enjoyed phases of swift growth and suffered severe recessions. In just three decades, the economy has gone from early industrialization, to de-industrialization and, more recently, to re-industrialization. Against the backdrop of these commotions, the structural change in manufacturing was accompanied by a generalised expansion of service activities, in the case of KIBS by a factor of two in less than twenty years.

Figure 5 gives a first glance into the interdependency between manufacturing and KIBS in the local labour markets of Spain. Changes in KIBS employment across all municipalities are plotted against initial manufacturing employment shares at the beginning of each decade. The positive relationship combined with the descriptive patterns outlined above leads us to expect that, on average, higher endowment of manufacturing know-how has spurred the development of complementary business service activities.

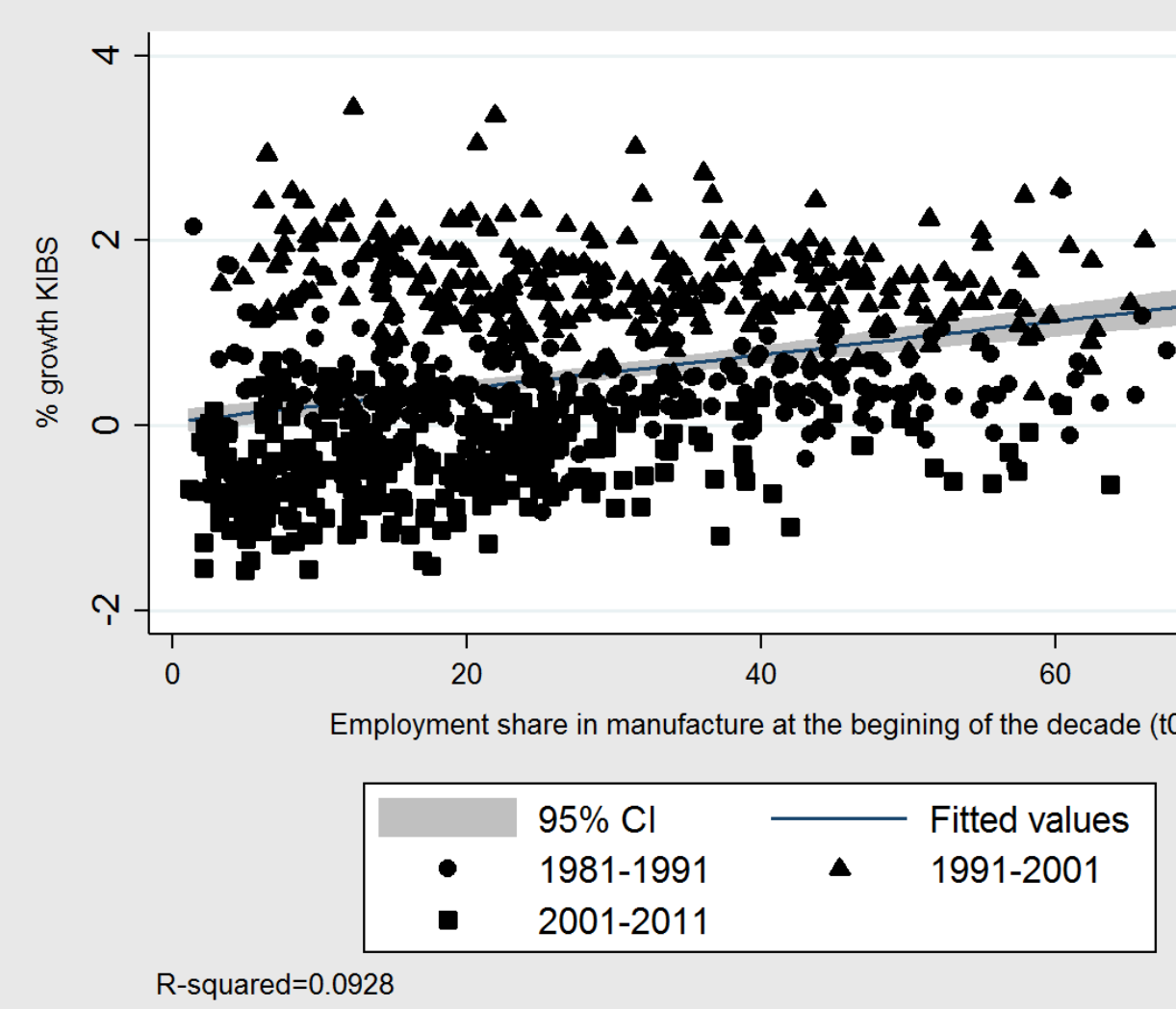

Figure 5. Employment change in KIBS (\%) by initial employment in manufacture 
Figures 6 and 7 illustrate the geography of employment at the municipality level. Each figure contains maps of the 399 areas, with province boundaries outlined in grey, in 1981 (upper panel) and in 2011 (lower panel). The interior of each municipality is shaded according to its quintile rank in the distribution of workforce employed in, respectively, KIBS and all manufacturing industries. Colour coding is darker for higher quintiles and progressively lighter for lower quintiles. Coherent with prior literature on the Spanish economy, both figures show that there is substantial spatial overlap between manufacturing and KIBS. These are especially concentrated in four large macro-areas: the region of Madrid; along the Mediterranean coast (from Andalusia, South East, to Catalonia in the North East); along the Ebro river valley (from Tarragona in the North East to the Basque Country in the North, going through the province of Zaragoza) and in the Northern shore that stretches from Pamplona (Navarra, North East) through to Coruña and Vigo (Galicia, North West) (see e.g. Maroto and Cuadrado, 2008; Prado de la Escosura, 2017). This map also underscores the gap of the above areas with the inland provinces that surround Madrid - i.e. Cuenca, Ciudad Real, Toledo, Avila, Soria, Teruel, as well as the Western provinces along the border with Portugal - from Huelva to Zamora. Finally, the figure shows no big change in the spatial distribution of industry over the three decades under analysis, with the exception of more intense clustering around the areas that were already industrialised. 


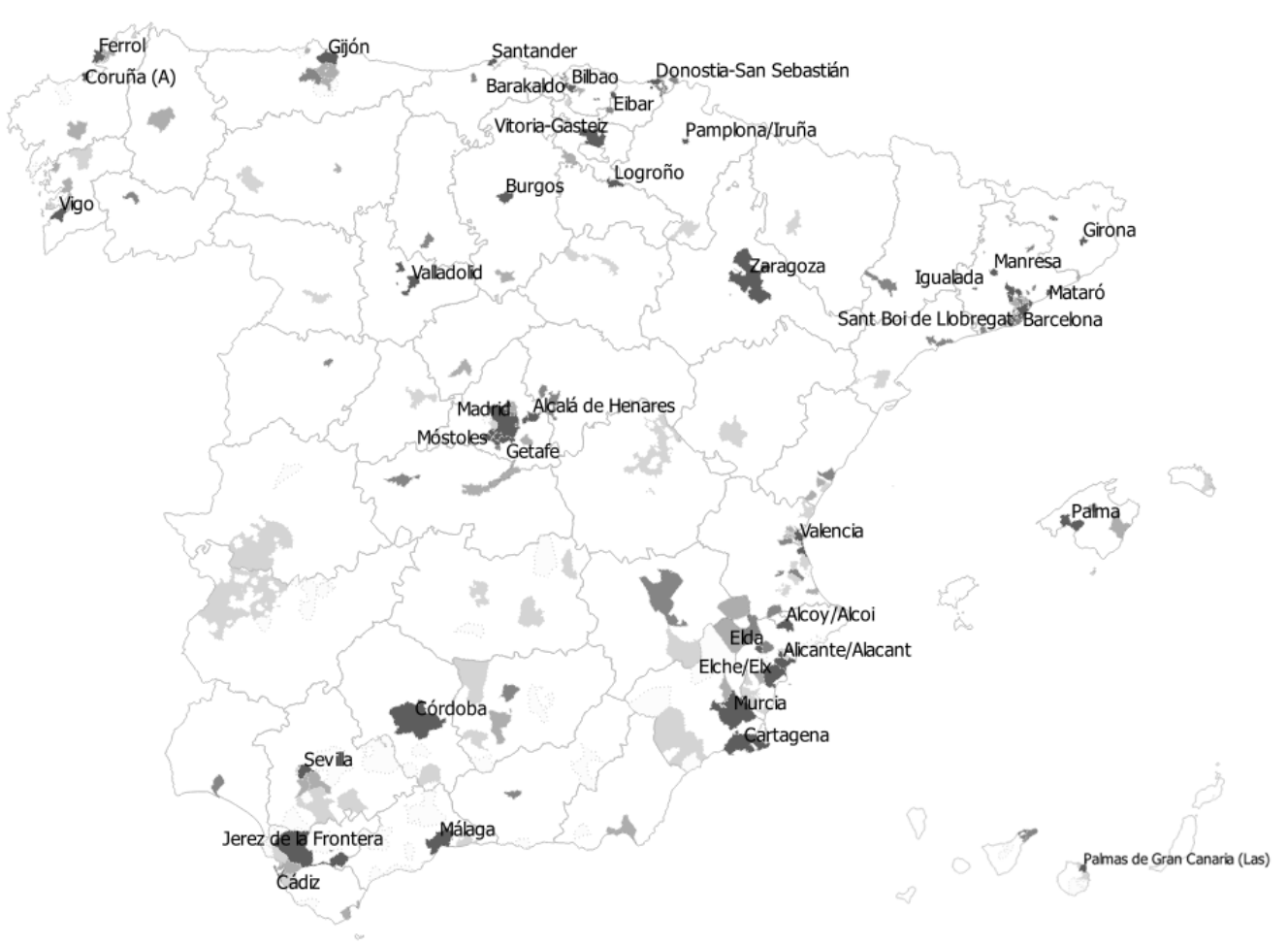

1981

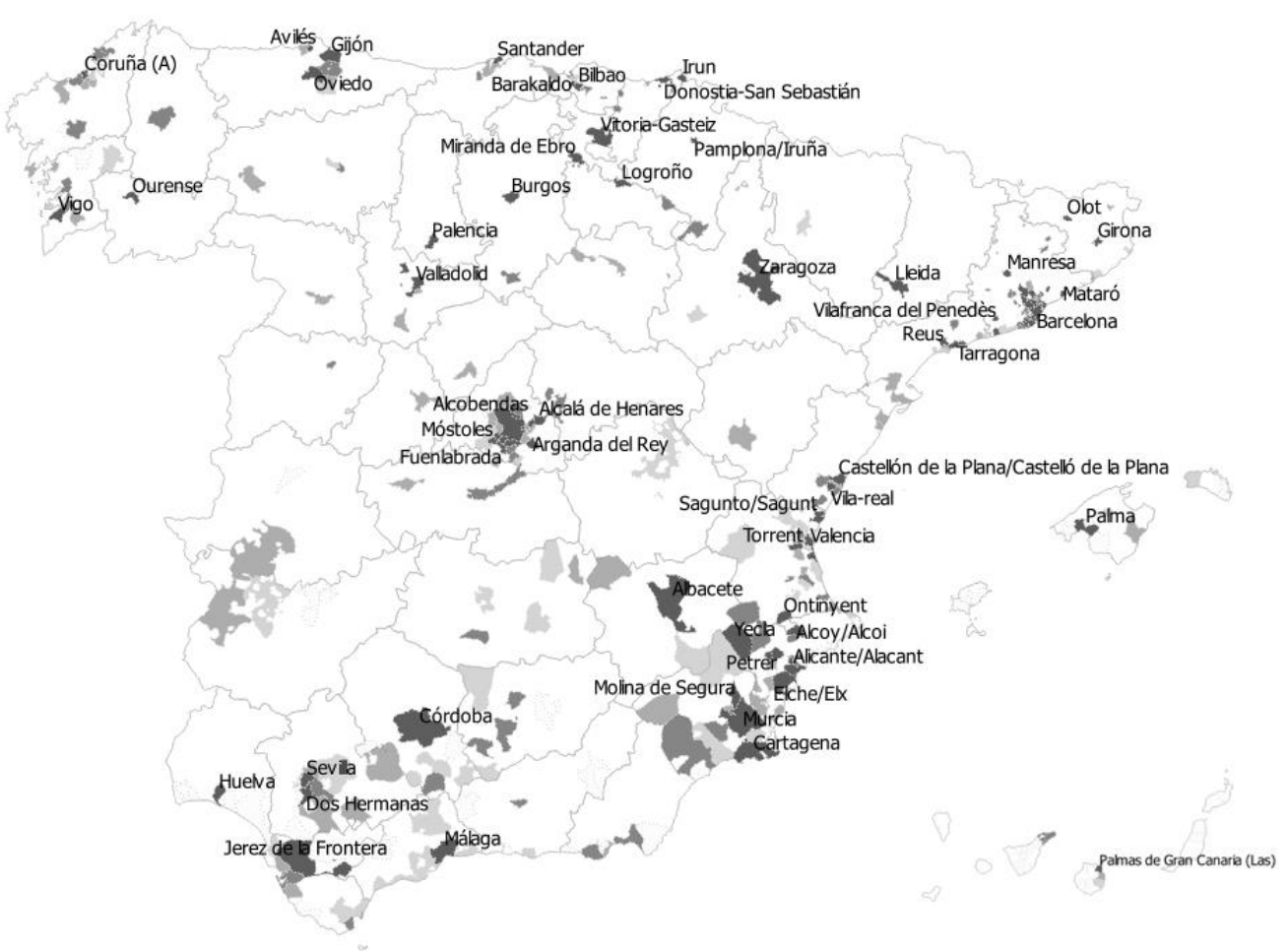

2011

Figure 6. top $20 \%$ municipalities by employment, manufacturing (dark gray) 


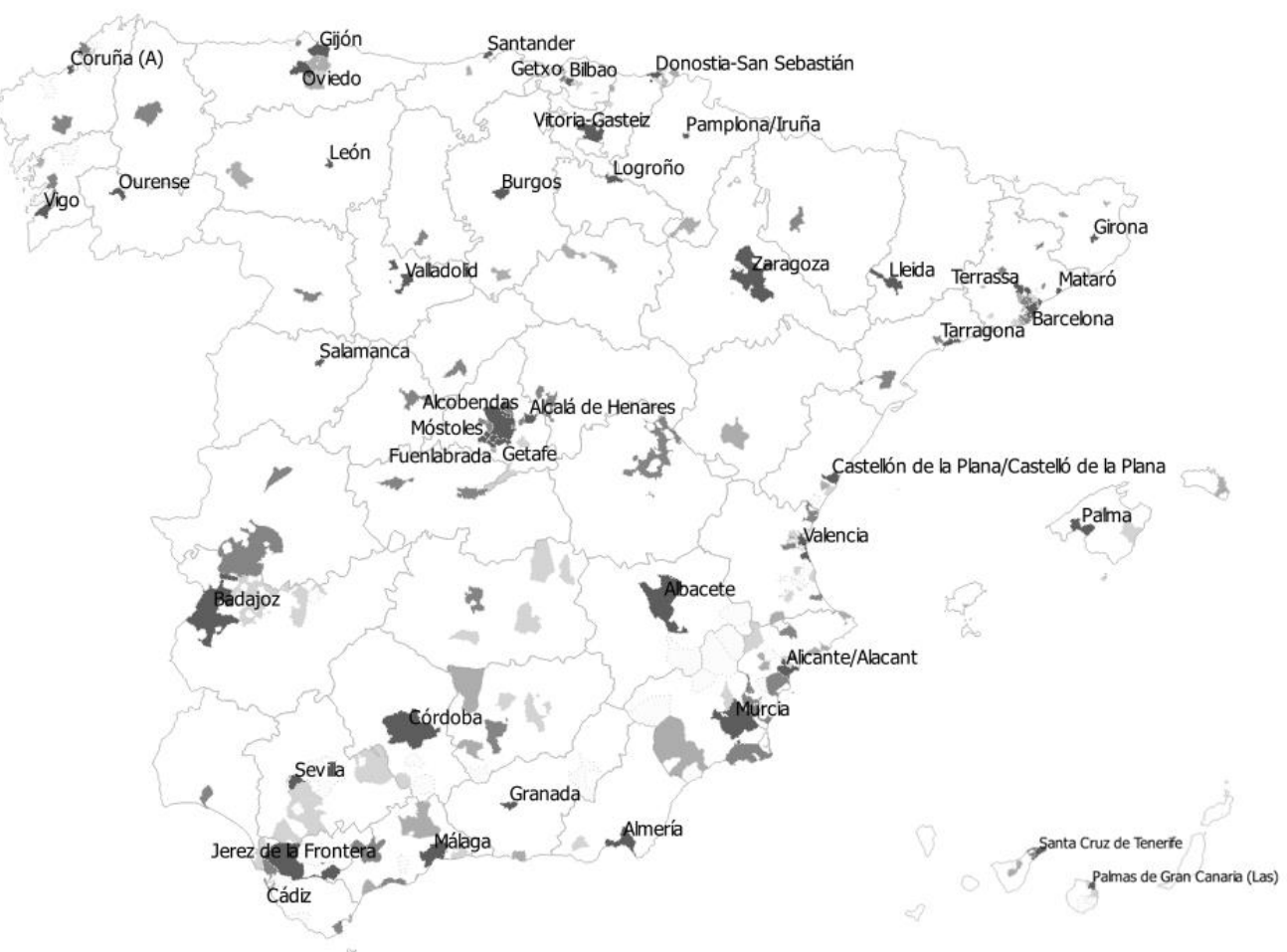

1981

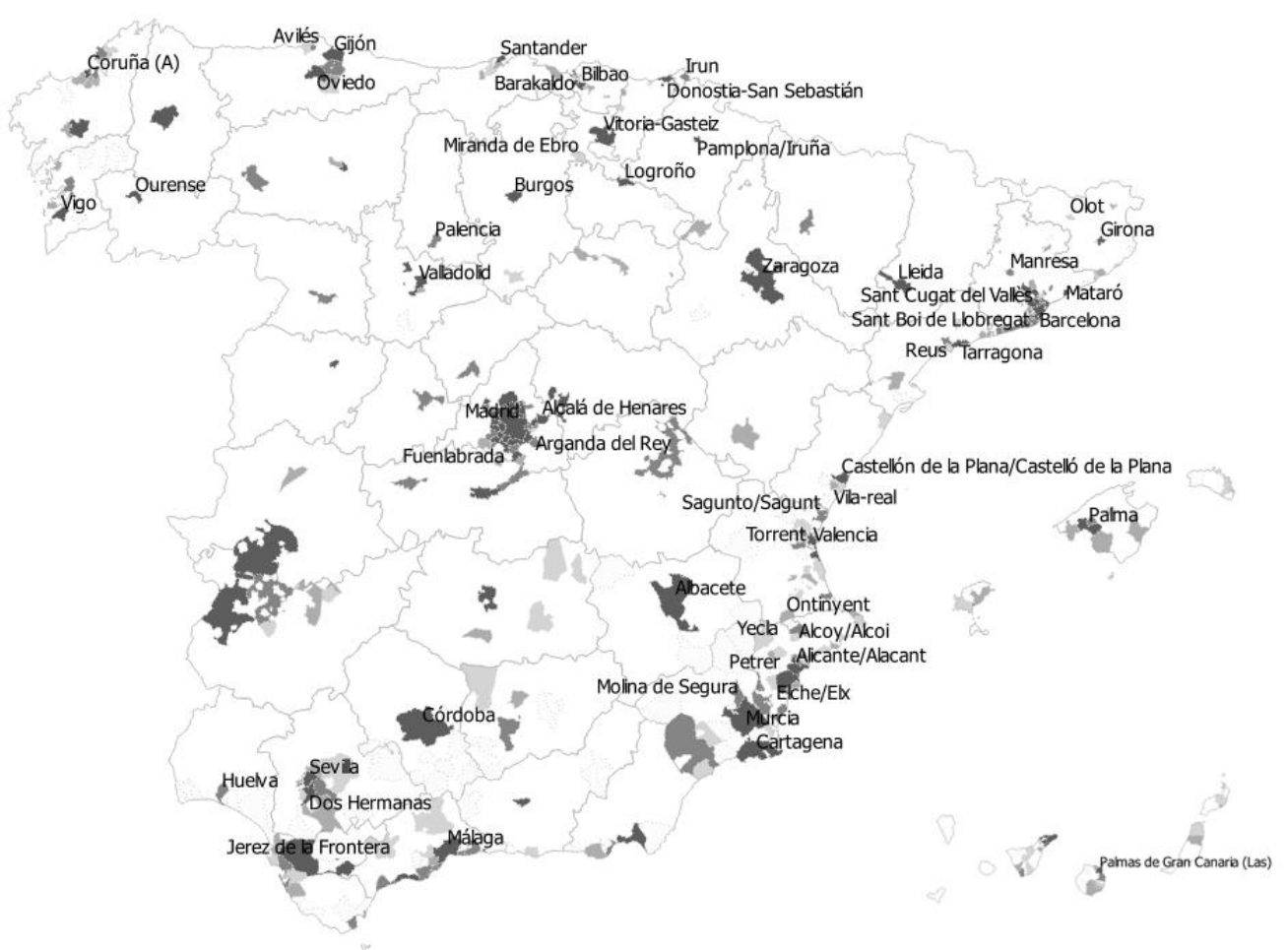

2011

Figure 7. top $20 \%$ municipalities by employment, KIBS (dark gray) 


\subsection{Empirical strategy}

Our empirical analysis of the interdependency between manufacturing and KIBS relies on the local multiplier approach (Black et al, 2005; Moretti, 2010; Moretti and Thulin, 2013; Marchand, 2012; Faggio and Overman, 2014; van Dijk, 2017). In the case at hand, we regress growth of regional employment in manufacturing on growth of local employment in KIBS controlling for unobserved province-specific fixed effects:

$$
\Delta K I B S_{m, t}=\alpha+\beta_{1} \Delta M a n u f_{m, t}+\beta_{2} T D U M+\varepsilon_{m t}
$$

where $\varepsilon_{m t}=\mu_{m}+v_{m t}, \Delta \mathrm{KIBS}_{m, t}$ and $\Delta M a n u f_{m, t}$ denote the ln employment of KIBS and manufacturing, respectively, in municipality $m$ and time $t=\left(t_{1}-t_{0}\right)$. TDUM is a time-dummy included to control for province shocks to employment. The error term $\varepsilon_{m t}$ is assumed to account for unobservable province-specific fixed effects, represented by $\mu_{m t}$, and a truly random component $v_{m t}$. In addition, because OLS estimates may be inconsistent in presence of unobserved shocks, we isolate exogenous shifts in the demand for labour in manufacturing using a shift-share instrumental variable (Moretti and Thulin, 2013 and Van Dijk, 2017). More specifically, we use the 10 sub-categories of the manufacturing sector (j) based on two-digit NACE to calculate the instrument for manufacturing employment growth in municipality $m$ at time $t$ as:

$$
\sum_{j} \operatorname{Manuf}_{m j t_{0}}\left[\ln \left(\operatorname{Manuf}_{j t_{1}}-\operatorname{Manuf}_{m j t_{1}}\right)-\ln \left(\operatorname{Manuf}_{j t_{0}}-\operatorname{Manuf}_{m j t_{0}}\right)\right]
$$

This calculation includes the national share and the industry mix components but excludes the local shift. In effect, of all the variations in employment in sub-industry $j$ in municipality $m$, the instrument isolates the variation that comes from nationwide changes in industry $\mathrm{j}$ (where nationwide changes are computed excluding municipality $m$ ). These changes at national level affect cities differently through their specific industry composition in the base year. To estimate the multipliers using IV for specific categories of the manufacturing sector we use a group-specific version of the shift-share instrument, that is, we apply the same formula but exclude the final sum for all sub-categories $j$. 


\subsection{Results}

Recall from the introduction that the first research question is: which manufacturing industries are complementary with KIBS development? To address this, we run OLS and IV estimates for all KIBS pooled together and, following Brenner et al (2017), by separating financial KIBS from non-financial KIBS. The explanatory variables are all manufacturing industries pooled together and each of the finer digit industries listed earlier (see Footnote 7). Entries in the rows are from 11 separate specifications while columns report the coefficient of the main explanatory variable, the number of observations, the Rsquared (for OLS) and the first-stage tests (for IV). For each pair of models our favourite specification is in the second column and includes the control variables: population characteristics (college/non-college ratio and presence of entrepreneurs), unemployment and migration.

The results of OLS estimates in our favourite specification (Table $3,2^{\text {nd }}$ column) indicate that, after the inclusion of the controls, only leather \& footwear and plastic \& chemicals have a positive job creation effect in KIBS. This pattern is somewhat different when KIBS sectors are partitioned between financial and non-financial activities. In the former (Table $3,4^{\text {th }}$ column) the positive and significant coefficients are those of manufacturing as a whole, metal, textile \& clothing and hi-tech. Conversely, leather \& footwear and plastic \& chemical drive job creation among non-financial KIBS (Table $3,6^{\text {th }}$ column). 
Table 3. Local Multiplier for KIBS growth (OLS)

\begin{tabular}{|c|c|c|c|c|c|c|c|c|c|c|c|c|c|c|c|c|c|c|}
\hline & \multicolumn{6}{|c|}{ All KIBS } & \multicolumn{6}{|c|}{ FINANCIAL KIBS } & \multicolumn{6}{|c|}{ NON- FINANCIAL KIBS } \\
\hline & $B$ & R2 & $\mathrm{N}$ & $B$ & $\mathrm{R} 2$ & $\mathrm{~N}$ & $B$ & R2 & $\mathrm{N}$ & $B$ & R2 & $\bar{N}$ & $B$ & R2 & $\mathrm{N}$ & $B$ & $\mathrm{R} 2$ & $\mathrm{~N}$ \\
\hline Manufacturing & $\begin{array}{c}0.119 \\
(0.091)\end{array}$ & 0.79 & 789 & $\begin{array}{c}0.141 \\
(0.093)\end{array}$ & 0.80 & 757 & $\begin{array}{l}0.231^{*} \\
(0.115)\end{array}$ & 0.82 & 809 & $\begin{array}{l}0.327^{* *} \\
(0.135)\end{array}$ & 0.84 & 778 & $\begin{array}{c}0.135 \\
(0.133)\end{array}$ & 0.91 & 788 & $\begin{array}{c}0.126 \\
(0.133)\end{array}$ & 0.91 & 769 \\
\hline Metal & $\begin{array}{l}-0.017 \\
(0.100)\end{array}$ & 0.79 & 773 & $\begin{array}{c}0.002 \\
(0.099)\end{array}$ & 0.80 & 744 & $\begin{array}{l}0.199^{\star *} \\
(0.085)\end{array}$ & 0.82 & 794 & $\begin{array}{l}0.218^{* *} \\
(0.085)\end{array}$ & 0.83 & 766 & $\begin{array}{c}-0.043 \\
(0.130)\end{array}$ & 0.91 & 776 & $\begin{array}{c}-0.049 \\
(0.131)\end{array}$ & 0.91 & 759 \\
\hline Food \& Tobacco & $\begin{array}{c}-0.019 \\
(0.057)\end{array}$ & 0.77 & 618 & $\begin{array}{c}-0.011 \\
(0.059)\end{array}$ & 0.78 & 589 & $\begin{array}{c}0.042 \\
(0.062)\end{array}$ & 0.82 & 628 & $\begin{array}{c}0.049 \\
(0.065)\end{array}$ & 0.83 & 599 & $\begin{array}{c}-0.031 \\
(0.049)\end{array}$ & 0.90 & 600 & $\begin{array}{c}-0.029 \\
(0.052)\end{array}$ & 0.90 & 584 \\
\hline Textile \& Clothing & $\begin{array}{c}0.063 \\
(0.042)\end{array}$ & 0.80 & 670 & $\begin{array}{c}0.064 \\
(0.042)\end{array}$ & 0.81 & 648 & $\begin{array}{c}0.0724^{* *} \\
(0.036)\end{array}$ & 0.82 & 686 & $\begin{array}{l}0.084^{*} \\
(0.042)\end{array}$ & 0.83 & 665 & $\begin{array}{l}-0.007 \\
(0.038)\end{array}$ & 0.91 & 674 & $\begin{array}{l}-0.013 \\
(0.036)\end{array}$ & 0.91 & 661 \\
\hline Leather \& Footwear & $\begin{array}{l}0.087^{\text {** }} \\
(0.035)\end{array}$ & 0.81 & 651 & $\begin{array}{l}0.092^{* *} \\
(0.037)\end{array}$ & 0.82 & 627 & $\begin{array}{l}-0.027 \\
(0.021)\end{array}$ & 0.82 & $\begin{array}{l}662 \\
588\end{array}$ & $\begin{array}{l}-0.016 \\
(0.022)\end{array}$ & 0.82 & 639 & $\begin{array}{c}0.136^{\star \star *} \\
(0.037)\end{array}$ & 0.914 & 651 & $\begin{array}{c}0.141^{* * *} \\
(0.044)\end{array}$ & 0.92 & 636 \\
\hline Wood \& Furniture & $\begin{array}{l}-0.033 \\
(0.076)\end{array}$ & 0.79 & 584 & $\begin{array}{l}-0.026 \\
(0.078)\end{array}$ & 0.79 & 562 & $\begin{array}{c}0.054 \\
(0.039)\end{array}$ & 0.82 & 588 & $\begin{array}{c}0.055 \\
(0.043)\end{array}$ & 0.83 & 566 & $\begin{array}{l}-0.085 \\
(0.099)\end{array}$ & 0.90 & 571 & $\begin{array}{l}-0.084 \\
(0.097)\end{array}$ & 0.91 & 556 \\
\hline Paper \& Editing & $\begin{array}{c}0.058 \\
(0.063)\end{array}$ & 0.80 & 686 & $\begin{array}{c}0.053 \\
(0.061)\end{array}$ & 0.80 & 669 & $\begin{array}{c}0.072 \\
(0.053)\end{array}$ & 0.82 & 707 & $\begin{array}{c}0.089 \\
(0.054)\end{array}$ & 0.83 & 691 & $\begin{array}{c}0.053 \\
(0.087)\end{array}$ & 0.91 & 697 & $\begin{array}{c}0.058 \\
(0.088)\end{array}$ & 0.91 & 685 \\
\hline Plastic \& Chemicals & $\begin{array}{l}0.115^{*} \\
(0.059)\end{array}$ & 0.81 & 719 & $\begin{array}{l}0.113^{*} \\
(0.059)\end{array}$ & 0.81 & 704 & $\begin{array}{l}-0.003 \\
(0.066)\end{array}$ & 0.82 & 738 & $\begin{array}{c}0.012 \\
(0.063)\end{array}$ & 0.82 & 724 & $\begin{array}{l}0.118^{*} \\
(0.059)\end{array}$ & 0.91 & 737 & $\begin{array}{l}0.113^{*} \\
(0.058)\end{array}$ & 0.91 & 727 \\
\hline Machinery & $\begin{array}{c}0.025 \\
(0.049)\end{array}$ & 0.79 & 632 & $\begin{array}{c}0.016 \\
(0.052)\end{array}$ & 0.80 & 613 & $\begin{array}{c}0.010 \\
(0.045)\end{array}$ & 0.82 & 643 & $\begin{array}{l}-0.003 \\
(0.045)\end{array}$ & 0.83 & 625 & $\begin{array}{c}0.017 \\
(0.051)\end{array}$ & 0.91 & 633 & $\begin{array}{c}0.012 \\
(0.054)\end{array}$ & 0.91 & 623 \\
\hline Transport Equipment & $\begin{array}{l}-0.018 \\
(0.054)\end{array}$ & 0.79 & 592 & $\begin{array}{l}-0.001 \\
(0.060)\end{array}$ & 0.80 & 582 & $\begin{array}{c}0.020 \\
(0.044)\end{array}$ & 0.82 & 599 & $\begin{array}{c}0.040 \\
(0.052)\end{array}$ & 0.83 & 590 & $\begin{array}{l}-0.027 \\
(0.062)\end{array}$ & 0.91 & 587 & $\begin{array}{c}-0.023 \\
(0.066)\end{array}$ & 0.91 & 583 \\
\hline Hi-Tech & $\begin{array}{c}0.053 \\
(0.037)\end{array}$ & 0.82 & 519 & $\begin{array}{c}0.055 \\
(0.037)\end{array}$ & 0.82 & 518 & $\begin{array}{c}0.102^{* * *} \\
(0.029)\end{array}$ & 0.84 & 533 & $\begin{array}{c}0.103^{* * *} \\
(0.029)\end{array}$ & 0.85 & 533 & $\begin{array}{c}0.025 \\
(0.053)\end{array}$ & 0.92 & 541 & $\begin{array}{c}0.024 \\
(0.052)\end{array}$ & 0.92 & 540 \\
\hline $\begin{array}{c}\text { College } \\
\text { Unemployment } \\
\text { Entrepreneurs } \\
\text { Migrants }\end{array}$ & & $\begin{array}{l}\mathrm{N} \\
\mathrm{N} \\
\mathrm{N} \\
\mathrm{N}\end{array}$ & & & $\begin{array}{l}Y \\
Y \\
Y \\
Y\end{array}$ & & & $\begin{array}{l}\mathrm{N} \\
\mathrm{N} \\
\mathrm{N} \\
\mathrm{N}\end{array}$ & & & $\begin{array}{l}Y \\
Y \\
Y \\
Y\end{array}$ & & & $\begin{array}{l}\mathrm{N} \\
\mathrm{N} \\
\mathrm{N} \\
\mathrm{N}\end{array}$ & & & $\begin{array}{l}Y \\
Y \\
Y \\
Y\end{array}$ & \\
\hline
\end{tabular}

Note: Each cell reports a separate regression. Regressions are weighted by population density (pop/km2).

Robust standard errors in parentheses are clustered by province. P-values: $*<0.1 ; * *<0.05 ; * * *<0.01$. 
The more robust IV estimates in Table 4 show a somewhat different pattern of interdependency and point to upward bias in OLS coefficients compared to the earlier results. Again, our favourite specification includes the full set of controls. When all KIBS are pooled together ( $2^{\text {nd }}$ column), we find that 9.4 new KIBS jobs are created for each manufacturing job. Looking at individual industries, when significant the effect is smaller: 0.6 for wood $\&$ furniture; 0.2 for leather $\&$ footwear and 0.1 for hi-tech manufacturing. ${ }^{11}$ Breaking the sample to keep separate financial and non-financial KIBS yields the same pattern of interdependence, and the only difference is the magnitude of the effect. In particular, the job multiplier is systematically higher for non-financial KIBS ( $6^{\text {th }}$ column) compared to financial KIBS ( $4^{\text {th }}$ column): 1.2 (compared to 0.6 ) in wood $\&$ furniture, 0.3 (0.2) in leather \& footwear, $0.2(0.1)$ in hi-tech.

\footnotetext{
${ }^{11}$ Following Moretti (2010) we quantify the magnitude of the multipliers by multiplying the elasticity against the relative size of the two sectors. We follow prior literature and concentrate on coefficients that are significant and on regressions that have a Kleibergen-Paap Wald F-statistic greater than 10.
} 
Table 4. Local Multiplier for KIBS growth (IV)

\begin{tabular}{|c|c|c|c|c|c|c|c|c|c|c|c|c|c|c|c|c|c|c|}
\hline & \multicolumn{6}{|c|}{ All KIBS } & \multicolumn{6}{|c|}{ FINANCIAL KIBS } & \multicolumn{6}{|c|}{ NON- FINANCIAL KIBS } \\
\hline & $\mathrm{B}$ & $\mathrm{Fa}^{\mathrm{a}}$ & $\mathrm{N}$ & $\mathrm{B}$ & $\mathrm{F}$ & $\mathrm{N}$ & $\mathrm{B}$ & $\mathrm{F}$ & $\mathrm{N}$ & $\mathrm{B}$ & $\mathrm{F}$ & $\mathrm{N}$ & $B$ & $\mathrm{~F}$ & $\mathrm{~N}$ & $B$ & $\mathrm{~F}$ & $\mathrm{~N}$ \\
\hline Manufacturing & $\begin{array}{c}2.570^{\star \star *} \\
(0.412)\end{array}$ & 94.67 & 789 & $\begin{array}{c}3.060^{\star \star \star \star} \\
(0.762)\end{array}$ & 41.58 & 757 & $\begin{array}{c}1.337^{\star \star \star} \\
(0.450)\end{array}$ & 97.1 & 771 & $\begin{array}{l}1.660^{\star \star \star} \\
(0.638)\end{array}$ & 39.49 & 740 & $\begin{array}{c}2.594^{* \star *} \\
(0.434)\end{array}$ & 95.39 & 749 & $\begin{array}{c}3.170^{\star \star \star} \\
(0.753)\end{array}$ & 39.78 & 730 \\
\hline Metal & $\begin{array}{c}8.257 \\
(13.40)\end{array}$ & 0.34 & 773 & $\begin{array}{c}9.064 \\
(11.46)\end{array}$ & 0.55 & 744 & $\begin{array}{c}4.924 \\
(8.133)\end{array}$ & 0.32 & 757 & $\begin{array}{l}6.197 \\
(7.365)\end{array}$ & 0.52 & 729.0 & $\begin{array}{c}12.21 \\
(25.15)\end{array}$ & 0.21 & 738 & $\begin{array}{c}12.92 \\
(20.48)\end{array}$ & 0.37 & 721 \\
\hline Food \& Tobacco & $\begin{array}{c}2.435 \\
(1.535)\end{array}$ & 1.99 & 618 & $\begin{array}{l}2.652^{*} \\
(1.427)\end{array}$ & 2.35 & 589.0 & $\begin{array}{l}1.654^{* *} \\
(0.841)\end{array}$ & 2 & 607 & $\begin{array}{l}1.776^{* *} \\
(0.702)\end{array}$ & 2.35 & 578.0 & $\begin{array}{c}2.407 \\
(1.604)\end{array}$ & 1.98 & 579 & $\begin{array}{l}2.611^{*} \\
(1.500)\end{array}$ & 2.38 & 563 \\
\hline Textile \& Clothing & $\begin{array}{l}7.186^{\star} \\
(4.362)\end{array}$ & 2.19 & 670 & $\begin{array}{c}4.810^{\star \star \star} \\
(1.624)\end{array}$ & 8.45 & 648 & $\begin{array}{c}3.576 \\
(2.439)\end{array}$ & 1.95 & 658 & $\begin{array}{c}2.434^{\star \star \star} \\
(0.901)\end{array}$ & 8.02 & 637 & $\begin{array}{c}7.420 \\
(4.779)\end{array}$ & 2.10 & 645 & $\begin{array}{c}4.937^{* * *} \\
(1.724)\end{array}$ & 8.42 & 632 \\
\hline Leather \& Footwear & $\begin{array}{c}0.516^{* * *} \\
(0.076)\end{array}$ & 27.98 & 651 & $\begin{array}{c}0.497^{* * *} \\
(0.067)\end{array}$ & 34.37 & 627 & $\begin{array}{c}0.264^{* * *} \\
(0.089)\end{array}$ & 26.98 & 637 & $\begin{array}{l}0.251^{* * *} \\
(0.0768)\end{array}$ & 32.7 & 614 & $\begin{array}{l}0.503^{* * *} \\
(0.0651)\end{array}$ & 27.99 & 625 & $\begin{array}{l}0.512^{* * *} \\
(0.0635)\end{array}$ & 34.21 & 610 \\
\hline Wood \& Furniture & $\begin{array}{c}2.718^{* * *} \\
(0.514)\end{array}$ & 35.67 & 584 & $\begin{array}{c}2.181^{* * *} \\
(0.324)\end{array}$ & 44.5 & 562 & $\begin{array}{c}1.859^{\star * \star} \\
(0.436)\end{array}$ & 23.45 & 575 & $\begin{array}{c}1.425^{\star * \star} \\
(0.285)\end{array}$ & 36.22 & 553 & $\begin{array}{c}2.387^{\star * *} \\
(0.409)\end{array}$ & 34.54 & 557 & $\begin{array}{c}2.044^{\star * \star} \\
(0.329)\end{array}$ & 44.07 & 542.0 \\
\hline Paper \& Editing & $\begin{array}{l}4.586^{* *} \\
(2.180)\end{array}$ & 3.61 & 686 & $\begin{array}{c}14.29 \\
(22.68)\end{array}$ & 0.35 & 669 & $\begin{array}{c}1.561 \\
(1.310)\end{array}$ & 3.62 & 675 & $\begin{array}{l}6.006 \\
(9.524)\end{array}$ & 0.39 & 659.0 & $\begin{array}{l}5.139^{* *} \\
(2.554)\end{array}$ & 3.35 & 664 & $\begin{array}{c}15.86 \\
(25.97)\end{array}$ & 0.32 & 652.0 \\
\hline Plastic \& Chemicals & $\begin{array}{c}0.829^{* * *} \\
(0.263)\end{array}$ & 14.4 & 719 & $\begin{array}{l}1.131^{* *} \\
(0.572)\end{array}$ & 5.45 & 704 & $\begin{array}{c}0.245 \\
(0.226)\end{array}$ & 12.79 & 704 & $\begin{array}{c}0.486 \\
(0.408)\end{array}$ & 5.13 & 690 & $\begin{array}{c}1.032^{* * *} \\
(0.332)\end{array}$ & 14.35 & 702.0 & $\begin{array}{l}1.307^{\star *} \\
(0.626)\end{array}$ & 5.25 & 692 \\
\hline Machinery & $\begin{array}{l}-2.962 \\
(3.825)\end{array}$ & 0.51 & 632 & $\begin{array}{c}3.555 \\
(3.926)\end{array}$ & 0.75 & 613 & $\begin{array}{l}-1.770 \\
(2.228)\end{array}$ & 0.46 & 620 & $\begin{array}{c}2.106 \\
(2.476)\end{array}$ & 0.82 & 602 & $\begin{array}{l}-3.097 \\
(4.289)\end{array}$ & 0.45 & 609 & $\begin{array}{c}3.499 \\
(3.775)\end{array}$ & 0.77 & 599 \\
\hline Transport Equipment & $\begin{array}{c}0.186 \\
(0.146)\end{array}$ & 4.12 & 592 & $\begin{array}{c}0.273 \\
(0.174)\end{array}$ & 4.78 & 582 & $\begin{array}{l}0.233^{* *} \\
(0.112)\end{array}$ & 4.1 & 582 & $\begin{array}{l}0.299^{* *} \\
(0.128)\end{array}$ & 4.79 & 573 & $\begin{array}{c}0.139 \\
(0.168)\end{array}$ & 4.07 & 570 & $\begin{array}{c}0.244 \\
(0.211)\end{array}$ & 4.67 & 566 \\
\hline $\mathrm{Hi}$-Tech & $\begin{array}{c}0.537^{\star \star \star} \\
(0.116) \\
\end{array}$ & 46.87 & 519 & $\begin{array}{c}0.526^{* * *} \\
(0.147)\end{array}$ & 29.08 & 518 & $\begin{array}{l}0.391^{* * *} \\
(0.059)\end{array}$ & 45.74 & 509 & $\begin{array}{l}0.345^{\star * *} \\
(0.0747)\end{array}$ & 28.95 & 509 & $\begin{array}{l}0.381^{*} \\
(0.202)\end{array}$ & 46.77 & 516 & $\begin{array}{l}0.468^{\star \star} \\
(0.232)\end{array}$ & 29.20 & 515 \\
\hline $\begin{array}{c}\text { College } \\
\text { Unemployment } \\
\text { Entrepreneurs } \\
\text { Migrants }\end{array}$ & & $\begin{array}{l}\mathrm{N} \\
\mathrm{N} \\
\mathrm{N} \\
\mathrm{N}\end{array}$ & & & $\begin{array}{l}Y \\
Y \\
Y \\
Y\end{array}$ & & & $\begin{array}{l}\mathrm{N} \\
\mathrm{N} \\
\mathrm{N} \\
\mathrm{N}\end{array}$ & & & $\begin{array}{l}Y \\
Y \\
Y \\
Y\end{array}$ & & & $\begin{array}{l}\mathrm{N} \\
\mathrm{N} \\
\mathrm{N} \\
\mathrm{N}\end{array}$ & & & $\begin{array}{l}Y \\
Y \\
Y \\
Y\end{array}$ & \\
\hline
\end{tabular}

Note: Each cell reports a separate regression. Regressions are weighted by population density (pop/km2).

Robust standard errors in parentheses are clustered by province. P-values: $*<0.1 ; * *<0.05$; $* * *<0.01$.

${ }^{a}$ Kleibergen-Paap rk Wald F-statistic. 
Turning to the second research question: do cross-sectoral interdependencies exhibit geographical heterogeneity? To address this question we apply the same empirical strategy by partitioning the sample into municipalities above or below the $66^{\text {th }}$ percentile of population density. ${ }^{12}$ Recall from the review of Section 2 that high levels of density are associated with higher likelihood of economies of scale and pecuniary externalities due to access to large markets and factor endowment. Results of the OLS estimates indicate very little job multiplier effect across the board. In areas with lower density, only food \& tobacco and leather $\&$ footwear have a significant impact, on financial and non-financial KIBS respectively (Table $5,2^{\text {nd }}$ and $3^{\text {rd }}$ columns). The effect of leather $\&$ footwear is also observed in denser municipalities $\left(4^{\text {th }}\right.$ and $6^{\text {th }}$ columns) together with metal and hi-tech for financial KIBS only ( $5^{\text {th }}$ column).

12 Population of the municipalities is calculated as the average value of the population between 1981 and 2011 using CENSUS information and taking into account the weights in each particular year. Results are substantially similar when the cut-off is set at the $75^{\text {th }}$ percentile of population density. 
Table 5. Local Multiplier for KIBS growth by size of the municipalities (OLS)

\begin{tabular}{|c|c|c|c|c|c|c|c|c|c|c|c|c|c|c|c|c|c|c|}
\hline & \multicolumn{9}{|c|}{ Sparse municipalities (below $66^{\text {th }}$ percentile) } & \multicolumn{9}{|c|}{ Dense municipalities (above or at $66^{\text {th }}$ percentile) } \\
\hline & \multicolumn{3}{|c|}{ All KIBS } & \multicolumn{3}{|c|}{ FINANCIAL KIBS } & \multicolumn{3}{|c|}{ NON- FINANCIAL KIBS } & \multicolumn{3}{|c|}{ All KIBS } & \multicolumn{3}{|c|}{ FINANCIAL KIBS } & \multicolumn{3}{|c|}{ NON- FINANCIAL KIBS } \\
\hline & $\mathrm{B}$ & $\mathrm{R} 2$ & $\mathrm{~N}$ & $\mathrm{~B}$ & $\mathrm{R} 2$ & $\mathrm{~N}$ & $\mathrm{~B}$ & $\mathrm{R} 2$ & $\mathrm{~N}$ & $\mathrm{~B}$ & $\mathrm{R} 2$ & $\mathrm{~N}$ & $\mathrm{~B}$ & $\mathrm{R} 2$ & $\mathrm{~N}$ & $\mathrm{~B}$ & $\mathrm{R} 2$ & $\mathrm{~N}$ \\
\hline Manufacturing & $\begin{array}{c}-0.07 \\
(0.089)\end{array}$ & 0.81 & 495 & $\begin{array}{c}-0.045 \\
(0.115)\end{array}$ & 0.75 & 481 & $\begin{array}{c}-0.165 \\
(0.12)\end{array}$ & 0.90 & 470 & $\begin{array}{c}0.235 \\
(0.149)\end{array}$ & 0.81 & 262 & $\begin{array}{l}0.448^{* *} \\
(0.130)\end{array}$ & 0.86 & 259 & $\begin{array}{c}0.213 \\
(0.207)\end{array}$ & 0.92 & 260 \\
\hline Metal & $\begin{array}{c}0.000 \\
(0.041)\end{array}$ & 0.82 & 484 & $\begin{array}{l}0.067 \\
(0.07)\end{array}$ & 0.75 & 472 & $\begin{array}{l}-0.063 \\
(0.054)\end{array}$ & 0.90 & 463 & $\begin{array}{c}-0.006 \\
(0.137)\end{array}$ & 0.81 & 260 & $\begin{array}{l}0.267^{*} \\
(0.115)\end{array}$ & 0.86 & 257 & $\begin{array}{l}-0.060 \\
(0.182)\end{array}$ & 0.92 & 258 \\
\hline Food \& Tobacco & $\begin{array}{c}-0.032 \\
(0.036)\end{array}$ & 0.79 & 362 & $\begin{array}{c}0.099^{*} \\
(0.045)\end{array}$ & 0.75 & 352 & $\begin{array}{l}-0.055 \\
(0.044)\end{array}$ & 0.89 & 338 & $\begin{array}{l}-0.008 \\
(0.065)\end{array}$ & 0.79 & 227 & $\begin{array}{c}0.037 \\
(0.077)\end{array}$ & 0.85 & 226 & $\begin{array}{c}-0.019 \\
(0.062)\end{array}$ & 0.91 & 225 \\
\hline Textile \& Clothing & $\begin{array}{c}0.036 \\
(0.024)\end{array}$ & 0.83 & 403 & $\begin{array}{c}0.06 \\
(0.038)\end{array}$ & 0.78 & 393 & $\begin{array}{c}-0.04 \\
(0.048)\end{array}$ & 0.91 & 389 & $\begin{array}{c}0.068 \\
(0.061)\end{array}$ & 0.81 & 245 & $\begin{array}{c}0.107 \\
(0.066)\end{array}$ & 0.85 & 244 & $\begin{array}{c}0.001 \\
(0.070)\end{array}$ & 0.92 & 243 \\
\hline Leather \& Footwear & $\begin{array}{c}0.049 \\
(0.035)\end{array}$ & 0.84 & 393 & $\begin{array}{c}0.023 \\
(0.032)\end{array}$ & 0.75 & 383 & $\begin{array}{l}0.095^{\star} \\
(0.043)\end{array}$ & 0.91 & 378 & $\begin{array}{l}0.095^{\star} \\
(0.042)\end{array}$ & 0.82 & 234 & $\begin{array}{l}-0.024 \\
(0.027)\end{array}$ & 0.84 & 231 & $\begin{array}{l}0.148^{*} \\
(0.054)\end{array}$ & 0.92 & 232 \\
\hline Wood \& Furniture & $\begin{array}{c}0.006 \\
(0.028)\end{array}$ & 0.80 & 333 & $\begin{array}{c}0.098 \\
(0.058)\end{array}$ & 0.81 & 327 & $\begin{array}{c}-0.05 \\
(0.052)\end{array}$ & 0.90 & 315 & $\begin{array}{l}-0.040 \\
(0.103)\end{array}$ & 0.80 & 229 & $\begin{array}{c}0.068 \\
(0.058)\end{array}$ & 0.85 & 226 & $\begin{array}{c}-0.099 \\
(0.135)\end{array}$ & 0.91 & 227 \\
\hline Paper \& Editing & $\begin{array}{l}0.001 \\
(0.04)\end{array}$ & 0.83 & 409 & $\begin{array}{c}0.029 \\
(0.047)\end{array}$ & 0.76 & 402 & $\begin{array}{c}-0.034 \\
(0.08)\end{array}$ & 0.90 & 394 & $\begin{array}{c}0.069 \\
(0.089)\end{array}$ & 0.81 & 260 & $\begin{array}{c}0.096 \\
(0.070)\end{array}$ & 0.85 & 257 & $\begin{array}{c}0.077 \\
(0.141)\end{array}$ & 0.92 & 258 \\
\hline Plastic \& Chemicals & $\begin{array}{c}0.009 \\
(0.057)\end{array}$ & 0.82 & 447 & $\begin{array}{c}-0.048 \\
(0.05)\end{array}$ & 0.76 & 436 & $\begin{array}{l}0.001 \\
(0.06)\end{array}$ & 0.91 & 436 & $\begin{array}{c}0.144 \\
(0.074)\end{array}$ & 0.82 & 257 & $\begin{array}{c}0.038 \\
(0.090)\end{array}$ & 0.85 & 254 & $\begin{array}{c}0.132 \\
(0.077)\end{array}$ & 0.92 & 256 \\
\hline Machinery & $\begin{array}{c}0.026 \\
(0.039)\end{array}$ & 0.82 & 357 & $\begin{array}{c}0.056 \\
(0.048)\end{array}$ & 0.78 & 349 & $\begin{array}{c}-0.019 \\
(0.052)\end{array}$ & 0.90 & 345 & $\begin{array}{c}0.015 \\
(0.065)\end{array}$ & 0.80 & 256 & $\begin{array}{l}-0.019 \\
(0.061)\end{array}$ & 0.85 & 253 & $\begin{array}{c}0.012 \\
(0.078)\end{array}$ & 0.92 & 254 \\
\hline Transport Equipment & $\begin{array}{c}-0.063 \\
(0.036)\end{array}$ & 0.81 & 343 & $\begin{array}{c}-0.001 \\
(0.043)\end{array}$ & 0.78 & 337 & $\begin{array}{l}-0.061 \\
(0.051)\end{array}$ & 0.89 & 329 & $\begin{array}{c}0.007 \\
(0.071)\end{array}$ & 0.81 & 239 & $\begin{array}{c}0.051 \\
(0.060)\end{array}$ & 0.85 & 236 & $\begin{array}{c}-0.024 \\
(0.076)\end{array}$ & 0.92 & 237 \\
\hline Hi-Tech & $\begin{array}{c}0.058 \\
(0.034) \\
\end{array}$ & 0.86 & 282 & $\begin{array}{c}0.025 \\
(0.038) \\
\end{array}$ & 0.81 & 276 & $\begin{array}{l}0.079 \\
(0.04)\end{array}$ & 0.93 & 279 & $\begin{array}{c}0.062 \\
(0.045) \\
\end{array}$ & 0.83 & 236 & $\begin{array}{l}0.126^{\star *} \\
(0.038)\end{array}$ & 0.86 & 233 & $\begin{array}{c}0.028 \\
(0.061) \\
\end{array}$ & 0.93 & 236 \\
\hline $\begin{array}{c}\text { College } \\
\text { Unemployment } \\
\text { Entrepreneurs } \\
\text { Migrants }\end{array}$ & & $\begin{array}{l}Y \\
Y \\
Y \\
Y\end{array}$ & & & $\begin{array}{l}Y \\
Y \\
Y \\
Y\end{array}$ & & & $\begin{array}{l}Y \\
Y \\
Y \\
Y\end{array}$ & & & $\begin{array}{l}Y \\
Y \\
Y \\
Y\end{array}$ & & & $\begin{array}{l}Y \\
Y \\
Y \\
Y\end{array}$ & & & $\begin{array}{l}Y \\
Y \\
Y \\
Y\end{array}$ & \\
\hline
\end{tabular}

Note: Each cell reports a separate regression. Regressions are weighted by population density (pop/km2).

Robust standard errors in parentheses are clustered by province. P-values: $*<0.1 ; * *<0.05$; $* * *<0.01$ 
The IV estimates yield a different picture (Table 6), more in line with the existing literature. In general, we find that the job multiplier effect of manufacturing on KIBS is stronger in municipalities with higher density. This is consistent with prior literature suggesting that agglomeration entails higher availability of skills and of labour market pooling opportunities. Indeed, the only significant impact we observe in sparse areas is the job multiplier effect of leather \& footwear (0.2 new financial KIBS jobs - Table $6,2^{\text {nd }}$ column). Things look different for larger areas wherein the pattern of interdependency is once again polarised. For all KIBS ( $3^{\text {rd }}$ column), significant employment effects are observed for supplier dominated industries like leather \& footwear and wood \& furniture ( 0.1 and 0.6 , respectively) as well as for the two science based industries plastic \& chemicals (0.3) and hi-tech (0.1). Leather \& footwear and hi-tech manufacturing have the same job multiplier on financial KIBS $\left(0.2-5^{\text {th }}\right.$ column $)$ while the effects on non-financial KIBS are due to leather $\&$ footwear (0.3), wood \& furniture (1.3) and plastic \& chemicals (0.9). Once again, the job multiplier is higher in non-financial KIBS. 
Table 6. Local Multiplier for KIBS growth by size of the municipalities (IV)

\begin{tabular}{|c|c|c|c|c|c|c|c|c|c|c|c|c|c|c|c|c|c|c|}
\hline & \multicolumn{9}{|c|}{ Sparse municipalities (below $66^{\text {th }}$ percentile) } & \multicolumn{9}{|c|}{ Dense municipalities (above or at $66^{\text {th }}$ percentile) } \\
\hline & \multicolumn{3}{|c|}{ All KIBS } & \multicolumn{3}{|c|}{ FINANCE } & \multicolumn{3}{|c|}{ NON- FINANCE } & \multicolumn{3}{|c|}{ All KIBS } & \multicolumn{3}{|c|}{ FINANCE } & \multicolumn{3}{|c|}{ NON- FINANCE } \\
\hline & $\mathrm{B}$ & $\mathrm{Fa}^{\mathrm{a}}$ & $\mathrm{N}$ & $\mathrm{B}$ & $\mathrm{F}$ & $\bar{N}$ & $\mathrm{~B}$ & $\bar{F}$ & $\mathrm{~N}$ & $\mathrm{~B}$ & $F$ & $\bar{N}$ & $B$ & $\bar{F}$ & $\bar{N}$ & $\mathrm{~B}$ & $\mathrm{~F}$ & $\mathrm{~N}$ \\
\hline Manufacturing & $\begin{array}{l}-1.486 \\
(1.632)\end{array}$ & 4.88 & 495 & $\begin{array}{c}-2.27 \\
(2.608)\end{array}$ & 0.57 & 481 & $\begin{array}{l}-1.897 \\
(2.228)\end{array}$ & 0.67 & 470 & $\begin{array}{c}2.811^{* \star \star} \\
(0.704)\end{array}$ & 42.26 & 262 & $\begin{array}{l}1.656^{*} \\
(0.661)\end{array}$ & 39.82 & 259 & $\begin{array}{c}2.941^{\star \star *} \\
(0.670)\end{array}$ & 40.04 & 260 \\
\hline Metal & $\begin{array}{c}-1.9 \\
(3.115)\end{array}$ & 0.63 & 484 & $\begin{array}{l}-2.501 \\
(3.565)\end{array}$ & 0.64 & 472 & $\begin{array}{l}-3.064 \\
(4.75)\end{array}$ & 0.71 & 463 & $\begin{array}{c}11.004 \\
(15.196)\end{array}$ & 0.44 & 260 & $\begin{array}{c}7.905 \\
(10.582)\end{array}$ & 0.43 & 257 & $\begin{array}{c}16.130 \\
(28.507)\end{array}$ & 0.29 & 258 \\
\hline Food \& Tobacco & $\begin{array}{l}0.363 \\
(0.3)\end{array}$ & 5.97 & 362 & $\begin{array}{c}0.798 \\
(0.539)\end{array}$ & 5.15 & 352 & $\begin{array}{c}0.317 \\
(0.338)\end{array}$ & 6.06 & 338 & $\begin{array}{l}2.410^{*} \\
(1.145)\end{array}$ & 2.46 & 227 & $\begin{array}{l}1.692^{\star *} \\
(0.553)\end{array}$ & 2.46 & 226 & $\begin{array}{c}2.362 \\
(1.227)\end{array}$ & 2.54 & 225 \\
\hline Textile \& Clothing & $\begin{array}{l}-0.648 \\
(0.526)\end{array}$ & 3.69 & 403 & $\begin{array}{l}-0.178 \\
(0.301)\end{array}$ & 4.34 & 393 & $\begin{array}{l}-0.751 \\
(0.482)\end{array}$ & 5.71 & 389 & $\begin{array}{l}5.017^{\star *} \\
(1.678)\end{array}$ & 7.22 & 245 & $\begin{array}{l}2.771^{* *} \\
(1.041)\end{array}$ & 7.14 & 244 & $\begin{array}{l}5.246^{\star *} \\
(1.815)\end{array}$ & 7.32 & 243 \\
\hline Leather \& Footwear & $\begin{array}{c}0.077 \\
(0.044)\end{array}$ & 16.67 & 393 & $\begin{array}{l}0.142^{* * *} \\
(0.038)\end{array}$ & 11.83 & 383 & $\begin{array}{c}0.077 \\
(0.051)\end{array}$ & 16.35 & 378 & $\begin{array}{c}0.569^{* * *} \\
(0.114)\end{array}$ & 20.58 & 234 & $\begin{array}{l}0.310^{*} \\
(0.122)\end{array}$ & 20.19 & 231 & $\begin{array}{c}0.580^{\star \star *} \\
(0.106)\end{array}$ & 20.22 & 232 \\
\hline Wood \& Furniture & $\begin{array}{c}0.527 \\
(0.455)\end{array}$ & 0.75 & 333 & $\begin{array}{c}0.658 \\
(0.605)\end{array}$ & 0.72 & 327 & $\begin{array}{c}0.513 \\
(0.513)\end{array}$ & 0.73 & 315 & $\begin{array}{c}2.341^{* \star *} \\
(0.502)\end{array}$ & 12.32 & 229 & $\begin{array}{l}1.714^{*} \\
(0.678)\end{array}$ & 9.62 & 226 & $\begin{array}{c}2.122^{* * *} \\
(0.409)\end{array}$ & 12.42 & 227 \\
\hline Paper \& Editing & $\begin{array}{c}1.033 \\
(1.153)\end{array}$ & 1.77 & 409 & $\begin{array}{c}1.523 \\
(1.555)\end{array}$ & 1.69 & 402 & $\begin{array}{c}0.833 \\
(1.461)\end{array}$ & 1.40 & 394 & $\begin{array}{c}41.881 \\
(229.572)\end{array}$ & 0.03 & 260 & $\begin{array}{c}18.466 \\
(91.847)\end{array}$ & 0.04 & 257 & $\begin{array}{c}50.654 \\
(301.290)\end{array}$ & 0.02 & 258 \\
\hline Plastic \& Chemicals & $\begin{array}{l}-0.032 \\
(0.092)\end{array}$ & 11.04 & 447 & $\begin{array}{c}-0.13 \\
(0.127)\end{array}$ & 11.03 & 436 & $\begin{array}{l}-0.113 \\
(0.122)\end{array}$ & 10.80 & 436 & $\begin{array}{c}0.845^{* * *} \\
(0.239)\end{array}$ & 14.70 & 257 & $\begin{array}{c}0.387 \\
(0.228)\end{array}$ & 13.61 & 254 & $\begin{array}{c}1.023^{* * *} \\
(0.267)\end{array}$ & 14.62 & 256 \\
\hline Machinery & $\begin{array}{c}0.564 \\
(1.184)\end{array}$ & 0.19 & 357 & $\begin{array}{l}1.256 \\
(2.17)\end{array}$ & 0.21 & 349 & $\begin{array}{c}0.592 \\
(1.375)\end{array}$ & 0.19 & 345 & $\begin{array}{l}2.767 \\
(2.480)\end{array}$ & 1.06 & 256 & $\begin{array}{c}1.731 \\
(1.730)\end{array}$ & 1.12 & 253 & $\begin{array}{l}2.796 \\
(2.458)\end{array}$ & 1.08 & 254 \\
\hline Transport Equipment & $\begin{array}{l}-0.062 \\
(0.042)\end{array}$ & 9.10 & 343 & $\begin{array}{c}0.06 \\
(0.048)\end{array}$ & 8.19 & 337 & $\begin{array}{l}-0.089 \\
(0.049)\end{array}$ & 8.91 & 329 & $\begin{array}{l}0.372^{*} \\
(0.182)\end{array}$ & 5.42 & 239 & $\begin{array}{l}0.396^{\star *} \\
(0.152)\end{array}$ & 5.40 & 236 & $\begin{array}{c}0.322 \\
(0.226)\end{array}$ & 5.17 & 237 \\
\hline $\mathrm{Hi}$-Tech & $\begin{array}{c}0.296 \\
(0.238)\end{array}$ & 1.97 & 282 & $\begin{array}{c}0.377 \\
(0.429)\end{array}$ & 1.94 & 276 & $\begin{array}{l}-0.221 \\
(0.465)\end{array}$ & 1.98 & 279 & $\begin{array}{l}0.397^{* *} \\
(0.130)\end{array}$ & 30.99 & 236 & $\begin{array}{c}0.310^{* * *} \\
(0.074)\end{array}$ & 31.61 & 233 & $\begin{array}{c}0.302 \\
(0.225) \\
\end{array}$ & 30.99 & 236 \\
\hline $\begin{array}{c}\text { College } \\
\text { Unemployment } \\
\text { Entrepreneurs } \\
\text { Migrants }\end{array}$ & & $\begin{array}{l}Y \\
Y \\
Y \\
Y\end{array}$ & & & $\begin{array}{l}Y \\
Y \\
Y \\
Y\end{array}$ & & & $\begin{array}{l}Y \\
Y \\
Y \\
Y\end{array}$ & & & $\begin{array}{l}Y \\
Y \\
Y \\
Y\end{array}$ & & & $\begin{array}{l}Y \\
Y \\
Y \\
Y\end{array}$ & & & $\begin{array}{l}Y \\
Y \\
Y \\
Y\end{array}$ & \\
\hline
\end{tabular}

Note: Each cell reports a separate regression. Regressions are weighted by population density (pop/km2).

Robust standard errors in parentheses are clustered by province. P-values: $*<0.1 ; * *<0.05 ; * * *<0.01$.

${ }^{\text {a }}$ Kleibergen-Paap rk Wald F-statistic. 


\subsection{Discussion}

Using Pavitt's (1984) renowned taxonomy as a guide, our results show that two types of industries exhibit consistent interdependency with KIBS sectors: supplier-dominated and science based.

The first supplier-dominated industry is wood \& furniture, the strongest driver of KIBS employment in our analysis. The aggregate pattern of Figure 2 shows that this industry recently enjoyed a slight rebound in employment after the decline of the 1980s and 1990s. The part of the sector concerning forestry, logging and timber trade is obviously tied to the availability of primary resources and is concentrated where wooden areas are most abundant, namely along the Northern shore (Pontevedra to Bilbao), and in the Northern provinces of Catalonia (Barcelona and Girona) - see Table A1. ${ }^{13}$ Most of these provinces are home to large and densely populated municipalities, which explains the persistence of the job multiplier effect in the second set of regressions in Table 6. Conversely, improvements in the transport infrastructure have lowered dependence on proximity to natural resources for the manufacturing of wooden products, especially furniture and toys, which is scattered around several parts of Spain, most prominently in the provinces of Cadiz, Sevilla, Cordoba (south of Andalucia), Alicante, Albacete, Valencia, around Madrid and in the North West (Pontevedra, A Coruña). According to a recent report, the regions of Valencia and of Catalonya together account for as much as $40 \%$ of overall employment (MINETUR, 2015; 2016). When municipalities are partitioned by density the job multiplier is only significant in non-financial KIBS, which we ascribe to the dominant mode of appropriability of this kind of activity, based on professional skills, aesthetic design, trademarks and advertising (Pavitt, 1984).

Leather \& footwear is the other supplier-dominated industry that emerges rather consistently in our analysis. Figure 2 shows that this activity has been in decline until 2000 but has stabilised thereafter. According to previous studies and reports, this traditional industry exhibits high geographical concentration with about $70 \%$ of the workforce employed along the Mediterranean coast, especially in the provinces of Alicante, Albacete,

\footnotetext{
${ }^{13}$ Detailed maps of industry employment by municipality are available in the Appendix.
} 
Valencia well as in the Balearic Islands (Boix and Galleto, 2006). Our findings resonate with this background in that the provinces of Alicante, Albacete and Toledo are home to municipalities in the lowest percentiles of population density (see results in Table 6) while about a third of the areas in the Balearic Islands are classified as high-density - see Table A2. One distinctive feature of leather \& footwear compared to wood \& furniture is the ample degree of interdependency with both financial and non-financial KIBS, the latter being a rather diverse group of activities that include among other things R\&D, Consultancy, Marketing, Legal and Accountancy services. This resonates with Pavitt's (1984) expectation that the in-house R\&D and engineering capabilities in these industries are weak.

The second macro-group of drivers of KIBS employment growth in Spain consists of two science based industries. It is worth reminding that according to Pavitt (1984) the main means of appropriation in this remit are $R \& D$ and strong connections with rapidly bodies of technical know-how in universities and elsewhere. The first industry in this group that stands out in our analysis is plastic \& chemicals. Figure 2 shows that, after a mild decline in the 1990s, this activity enjoyed a rebound in the most recent decade. As concerns the geographical distribution, chemical production in Spain exhibits high levels of concentration, mostly due to decline in the northern provinces of the Basque Country (Vitoria and Bilbao) and the resilience of activities in the provinces of Barcelona and Madrid - see Figure A3. On the other hand, rubber and plastic material transformation is more dispersed, due to the mushrooming of clusters along the Mediterranean shore in highdensity provinces like Murcia, Valencia, Castellon, Tarragona and Barcelona. Taken all together these account for over $30 \%$ of this industry's total employment (MINETUR 2015).

The second science based industry includes various branches such as high technology such as production of electric and electronic components, robotics and information and communication technologies. Figure 2 shows that, all together, after expanding to more than $2.5 \%$ of total national employment during the $1980 \mathrm{~s}$, the industry has faced a steady decline, albeit milder compared to others, over the last two decades. Looking into the component branches, electronic components is the most traditional and most geographically dispersed according to the location of the main user industries. Thereby, production of electronic components for vehicles tends to cluster around traditional 
strongholds of car and truck production and assemblage in Barcelona, Valencia, Valladolid, Zaragoza and Madrid, while production of electronic components for airplanes are based in the vicinity of aeronautics industry centres that have emerged in Madrid, Cádiz and Sevilla. Other specialized electronic components aimed at the defence industry are in Madrid, País Vasco, Coruña, Malaga and Murcia. Conversely, consumer electronics faced the challenge of consolidation and growing foreign competition beginning the late 1990s and is now mainly concentrated in Barcelona. The robotics branch has enjoyed steady growth, even in spite of the recent financial crisis, and has three core locations in Madrid, Barcelona and in País Vasco (ONTSI, 2015). Finally, the information and communication technologies industry has grown during the 1990s but suffered heavy employment losses during the most recent financial crisis. This branch of the hi-tech industry is geographically concentrated in Madrid and in Catalonia that together are home to more than $50 \%$ of all business firms - see Fig. A4.

In the absence of more detailed information about the flow of inputs and outputs across sectors, we can only speculate on the roots of the dualism between traditional and modern industries which our results point to. KIBS provide knowledge inputs that industries absorb and embed into their products and processes. A trademark assumption on the evolution of capitalism is that firms operating in mature industries confront different challenges, either due to the appearance of new competitors or of unexplored market opportunities. In the face of either, developing routines of knowledge production and use is essential to pursue, maintain or restore the competitive edge. Accordingly, as industries move along the life cycle new types of know-how become necessary and, with that, new sources to tap into. In this tenet KIBS perform a dual function, by both facilitating the crystallisation of routinized knowledge where the scope for novelty has petered out, such as the case of traditional and established activities like leather \& footwear, as well as opening up new horizons where the need for novelty remains urgent, which is instead the case of science-based industries like plastic \& chemicals and hi-tech. 


\section{Concluding remarks}

Drawing on an established strand of conceptual research in innovation studies this study has construed the emergence KIBS as a physiological step in the evolution of capitalist economies. We explore these themes by focusing on the long term interdependency of KIBS and manufacturing in the Spanish economy. Methodologically, we rely on employment data that provide a direct measure of the changing relative importance of industries' knowledge bases.

Retrospectively, our results resonate with previous literature by showing that KIBS are diverse and that, accordingly, they complement manufacturing industries selectively, with different intensity and not equally everywhere. More to the point, the analysis of employment data in Spanish municipalities over three decades reveals, perhaps in touching with the generalised perception of this country, a continuum between tradition and modernity. Using a job multiplier technique we find that four manufacturing industries have a positive employment effect on KIBS: two traditional supplier dominated industries - leather \& footwear and wood \& furniture - and two emergent science based industries plastic \& chemicals and hi-tech manufacturing.

Prospectively, our study indicates several avenues for further research. One key question concerns the types of knowledge interaction that are relevant for the interdependency between manufacturing and KIBS. A satisfactory answer would require a suitable intersectoral matrix to capture the gateways and the pathways of these knowledge flows. A related, and unexplored issue, concerns the need to evaluate more satisfactorily the extent to which these flows are direct and/or indirect. We expect that in a mature industry the relative knowledge flow occurs mainly in the form of intermediate inputs to enhance the efficiency of transforming a known resource (i.e. leather) into a final product (i.e. footwear) with a finite spectrum of uses. But in the case of dynamic industries, the final product (i.e. a computer) could somehow reverse the flow and need further intermediate input, or different a type of intermediate input, for the range of applicability is vast and, potentially, still expanding. A technical consultancy service that enhances an electronic device which is subsequently an input into $R \& D$ or engineering consulting is an instance of this iterative feedback. This is just a way to say that KIBS' heterogeneity is not just cross-sectoral but, also, intertemporal. Growing availability of large datasets bode well for the viability of future research on these issues. 


\section{Bibliography}

Antonietti, R., Cainelli, G., Lupi, C. (2013). Vertical disintegration and spatial colocalization: The case of Kibs in the metropolitan region of Milan. Economics Letters, 118(2), 360-363.

Aslesen, H.W., Jakobsen, S.E. (2007). The role of proximity and knowledge interaction between head offices and KIBS. Tijdschrift voor Economische en Sociale Geografie, 98(2), 188-201.

Bartik, T.J. 1991. Who benefits from state and local economic development policies? Upjohn Institute Press, Kalamazoo.

Black, D., McKinnish, T., Sanders, S. (2005). The economic impact of the coal boom and bust. The Economic Journal, 115(503), 449-476.

Boden, M., Miles, I. (Eds.) (2000). Services and the Knowledge-based Economy. Psychology Press.

Boix, R., Galleto, V. (2006). Sistemas locales de trabajo y distritos industriales marshallianos en España. Economía Industrial, (359), 165-184.

Brenner, T., Capasso, M., Duschl, M., Frenken, K., Treibich, T. (2017). Causal relations between knowledge-intensive business services and regional employment growth. Regional Studies, 1-12.

Buesa, M. and Molero, J. (1998). Economía industrial de España. Organización, tecnología e internacionalización. Madrid, Civitas.

Ciarli, T., Meliciani, V., Savona, M. (2012) Knowledge dynamics, structural change and the geography of business services. Journal of Economic Surveys, 26, 445-467.

Ciriaci, D., Montresor, S., Palma, D. (2015). Do KIBS make manufacturing more innovative? An empirical investigation of four European countries. Technological Forecasting and Social Change, 95, 135-151.

Consoli, D., Elche-Hortelano, D. (2010). Variety in the knowledge base of Knowledge Intensive Business Services. Research Policy, 39(10), 1303-1310.

Cooke, P., Leydesdorff, L. (2006). Regional development in the knowledge-based economy: the construction of advantage. Journal of Technology Transfer, 31, 5-15. 
Corrocher, N., Cusmano, L. (2014). The 'KIBS engine' of regional innovation systems: Empirical evidence from European regions. Regional Studies, 48(7), 1212-1226.

Den Hertog, P. (2000). Knowledge-intensive business services as co-producers of innovation. International Journal of Innovation Management 4, 491-528.

Duranton, G., Puga, D. (2005). From sectoral to functional urban specialisation. Journal of urban Economics, 57(2), 343-370.

Faggio, G., Overman, H. (2014). The effect of public sector employment on local labour markets. Journal of urban economics, 79, 91-107.

Freel, M. (2006). Patterns of technological innovation in knowledge-intensive business services. Industry and Innovation, 13(3), 335-358.

Fujita, M., Tabuchi, T. (1997). Regional growth in postwar Japan. Regional Science and Urban Economics, 27(6), 643-670.

Garrido, R. (2002): Cambio estructural y desarrollo regional en España, Ed. Pirámide, Madrid.

Henderson, J.V. (1988). Urban Development: Theory, Fact and Illusion. Oxford: Oxford University Press.

Herstad, S. J., Ebersberger, B. (2014). Urban agglomerations, knowledge-intensive services and innovation: Establishing the core connections. Entrepreneurship and Regional Development, 26(3-4), 211-233.

Jacobs, W., Koster, H. R., \& van Oort, F. (2014). Co-agglomeration of knowledgeintensive business services and multinational enterprises. Journal of Economic Geography, 14(2), 443-475. doi:10. 1093/jeg/lbs055

Kline, S. J., Rosenberg, N. (1986). An overview of innovation. The positive sum strategy: Harnessing technology for economic growth, 14, 640.

Koch, A., Stahlecker, T. (2006). Regional innovation systems and the foundation of knowledge intensive business services. A comparative study in Bremen, Munich, and Stuttgart, Germany. European Planning Studies, 14(2), 123-146.

Kolko, J. (2010). Urbanization, agglomeration, and coagglomeration of service industries. In Agglomeration economics, 151-180). University of Chicago Press. 
Kolko, J. (1999). Can I get some service here? Information technologies, service industries and the future of cities. Processed, Harvard University.

Kox, H., Rubalcaba, L. (2007). The contribution of business services to European economic growth. In Business services in European economic growth (pp. 74-94). Palgrave Macmillan UK.

Kuusisto, J., Meyer, M. (2003). Insights into services and innovation in the knowledge intensive economy. Technology Review 134/2003, Tekes, Helsinki.

Malhotra, N., Morris, T. (2009). Heterogeneity in professional service firms. Journal of Management Studies, 46(6), 895-922.

Marchand, J. (2012). Local labor market impacts of energy boom-bust-boom in Western Canada. Journal of Urban Economics, 71(1), 165-174.

Maroto, A. and Cuadrado, J.R. (2008). Evolución de la productividad en España. Un análisis sectorial, 1980-2006. Economía Industrial, 367: 15-34

MINETUR (2015). Informes Sectoriales Anuales. Secretaría General Técnica. Subdirección General de Estudios, Análisis y Planes de Actuación. Ministerio de Industria, Energía y Turismo.

MINETUR (2016). Informes Sectoriales Anuales. Secretaría General Técnica. Subdirección General de Estudios, Análisis y Planes de Actuación. Ministerio de Industria, Energía y Turismo.

Meliciani, V., Savona, M. (2014). The determinants of regional specialisation in business services: agglomeration economies, vertical linkages and innovation. Journal of Economic Geography, 15(2), 387-416.

Metcalfe, J.S. (2014). Capitalism and evolution. Journal of Evolutionary Economics, 24(1), 11-34.

Miles, I. (2005). Knowledge intensive business services: prospects and policies, Foresight, $7(6), 39-63$

Miles, I., Kastrinos, N., Flanagan, K., Bilderbeek, R., den Hertog, B., Huntink, W., Bouman, M., (1995). Knowledge-intensive Business Services: Users, Carriers and Sources of Innovation. European Innovation Monitoring System (EIMS), EIMS Publication No. 15, Luxembourg. 
Moretti, E. (2010). Local multipliers. The American Economic Review, 100(2), 373-377.

Moretti, E., Thulin, P. (2013). Local multipliers and human capital in the United States and Sweden. Industrial and Corporate Change, 22(1), 339-362.

Muller, E., Doloreux, D. (2009). What we should know about knowledge-intensive business services. Technology in society, 31(1), 64-72.

Muller, E., Zenker, A. (2001). Business services as actors of knowledge transformation: the role of KIBS in regional and national innovation systems. Research policy, 30(9), 15011516.

Observatorio Nacional de las Telecomunicaciones y de la SI [ONTSI] (2015). El sector TIC y de los Contenidos en España 2015. Informe Anual. Observatorio Nacional de las Telecomunicaciones y de la SI. Ministerio de Industria, Energía y Turismo.

Pavitt, K. (1984). Sectoral patterns of technical change: towards a taxonomy and a theory. Research policy, 13(6), 343-373.

Pavitt, K. (2002). Innovating routines in the business firm: what corporate tasks should they be accomplishing? Industrial and Corporate Change 11(1), 117-133.

Pérez, F., Maudos, J., Pastor, J.M., Serrano, L. (eds.) (2006): Productividad e internacionalización: el crecimiento español ante los nuevos cambios estructurales, Fundación BBVA, Madrid.

Pina, K., Tether, B.S. (2016). Towards understanding variety in knowledge intensive business services by distinguishing their knowledge bases. Research Policy, 45(2), 401413.

Prados de la Escosura, L. (2017) Spanish Economic Growth, 1850-2015. Palgrave McMillan.

Shearmur, R., Doloreux, D. (2009). Place, space and distance: towards a geography of knowledgeintensive business services innovation. Industry and Innovation, 16, 79-102.

Shilton, L., Stanley, C. (1999). Spatial patterns of headquarters. Journal of Real Estate Research, 17(3), 341-364. 
Simmie, J., Strambach, S. (2006). The contribution of KIBS to innovation in cities: an evolutionary and institutional perspective. Journal of Knowledge Management, 10(5), 2640.

Strambach S. (1998). Knowledge-intensive business services (KIBS) as an element of learning regions - the case of Baden Württenberg, in European Regional Science Association (ERSA) Conference Papers.

Strambach, S. (2008). Knowledge-Intensive Business Services (KIBS) as drivers of multilevel knowledge dynamics. International journal of services technology and management, 10(2-4), 152-174.

Tether, B.S., Hipp, C. (2002). Knowledge intensive, technical and other services: patterns of competitiveness and innovation compared. Technology Analysis \& Strategic Management, 14(2), 163-182.

Van Dijk, J. J. (2016). Local employment multipliers in US cities. Journal of Economic Geography, 17(2), 465-487.

Von Nordenflycht, A. (2010). What is a professional service firm? Toward a theory and taxonomy of knowledge-intensive firms. Academy of management Review, 35(1), 155 174.

Wernerheim, C.M., Sharpe, C. (2003). High Order'Producer Services in Metropolitan Canada: How Footloose Are They?. Regional Studies, 37(5), 469-490.

Wood, P.A., Bryson, J., Keeble, D. (1993). Regional patterns of small firm development in the business services: evidence from the United Kingdom. Environment and Planning A, 25(5), 677-700. 


\section{Appendix}

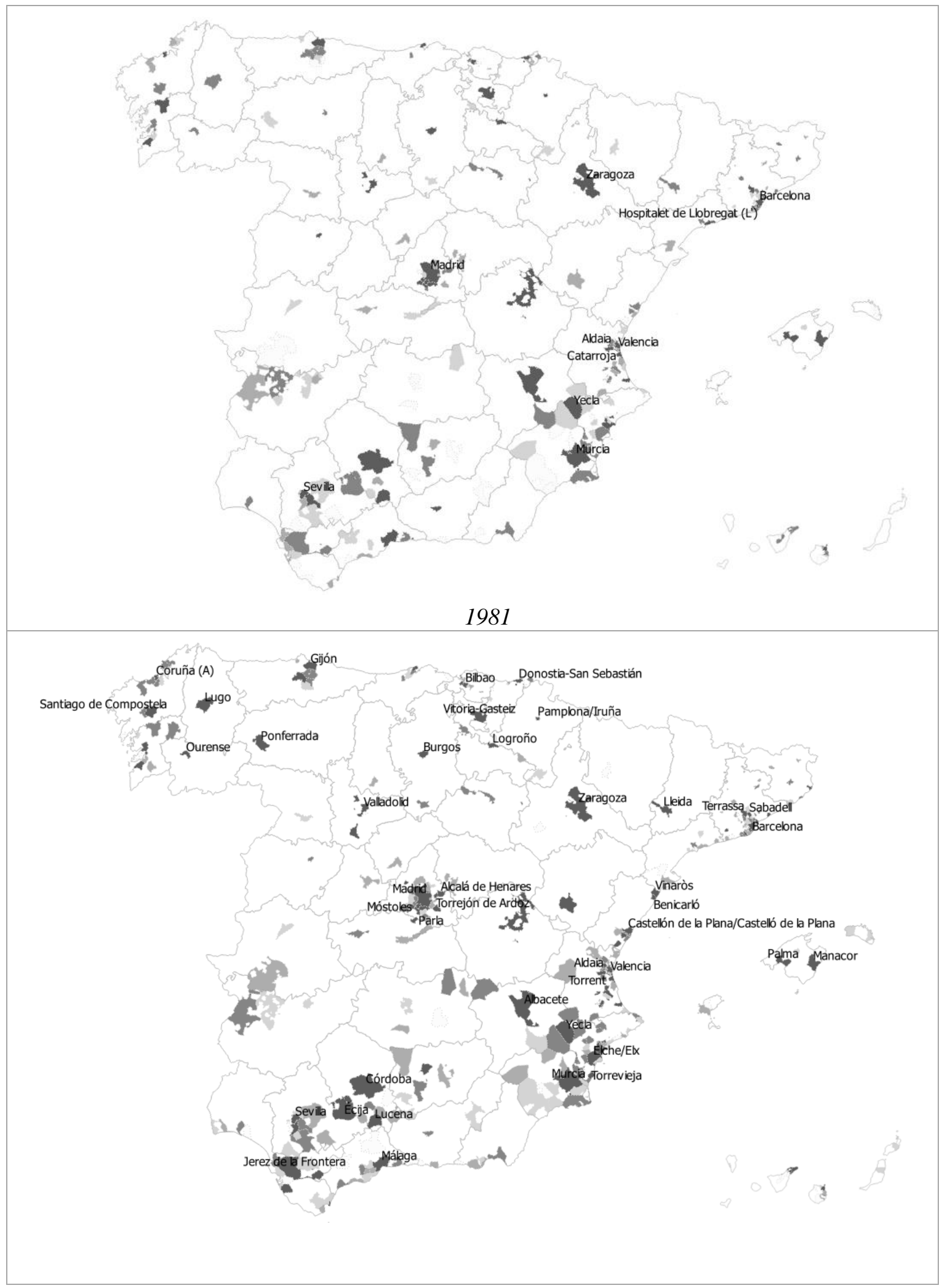

Figure A3. top $20 \%$ municipalities by employment, wood \& furniture (dark grey) 


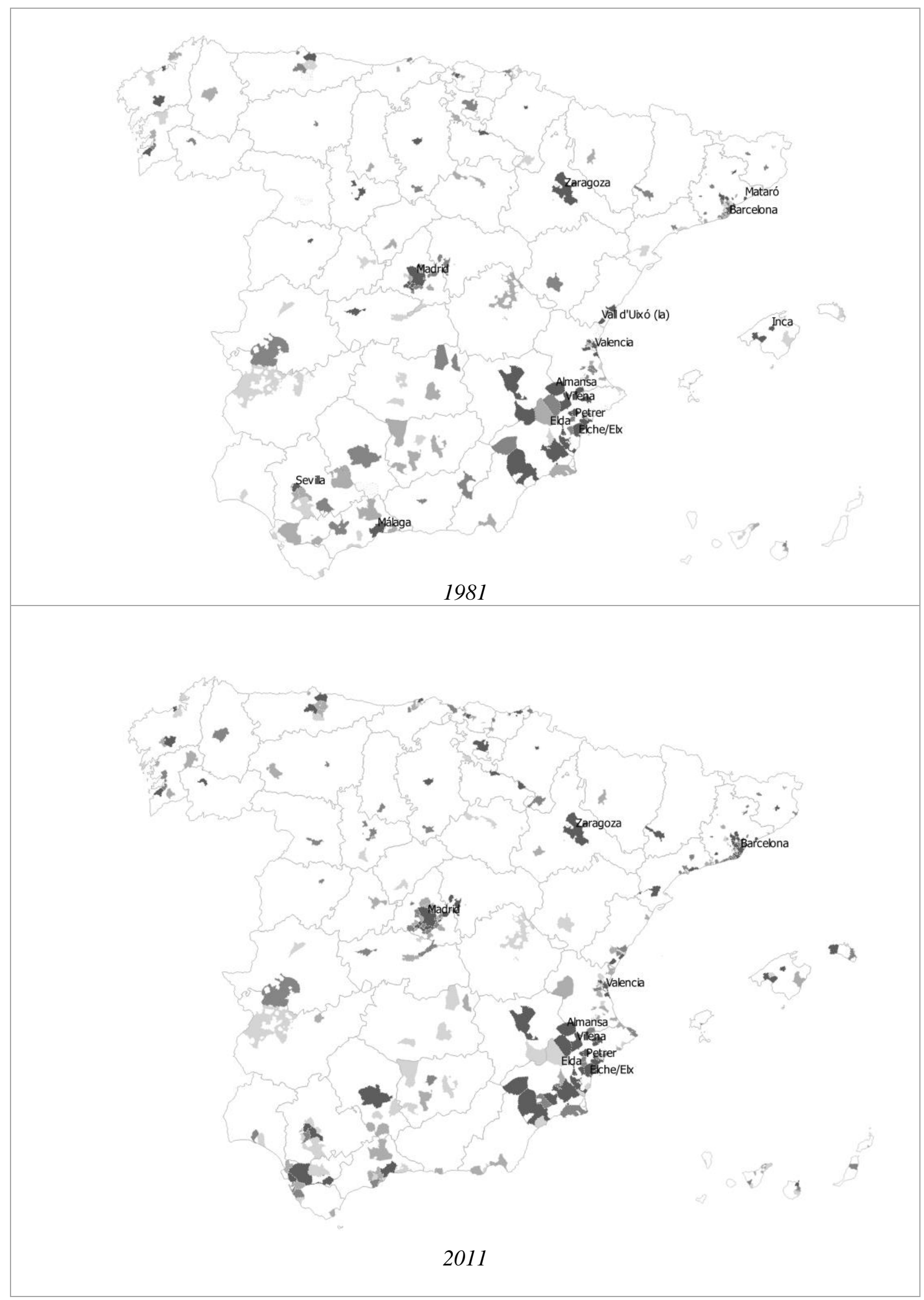

Figure A4. top $20 \%$ municipalities by employment, leather \& footwear (dark grey) 


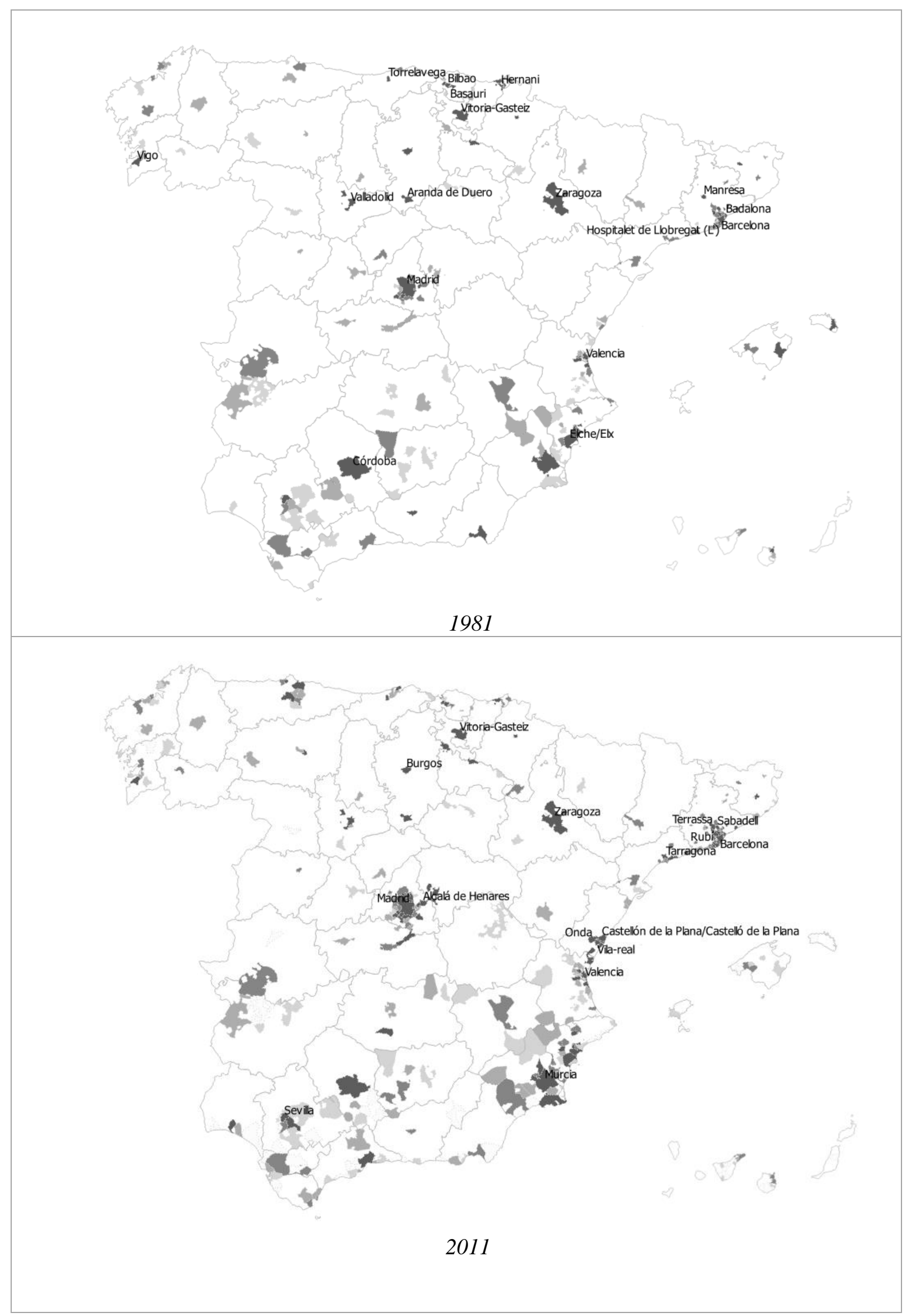

Figure A5. top $20 \%$ municipalities by employment, plastic \& chemicals (dark grey) 


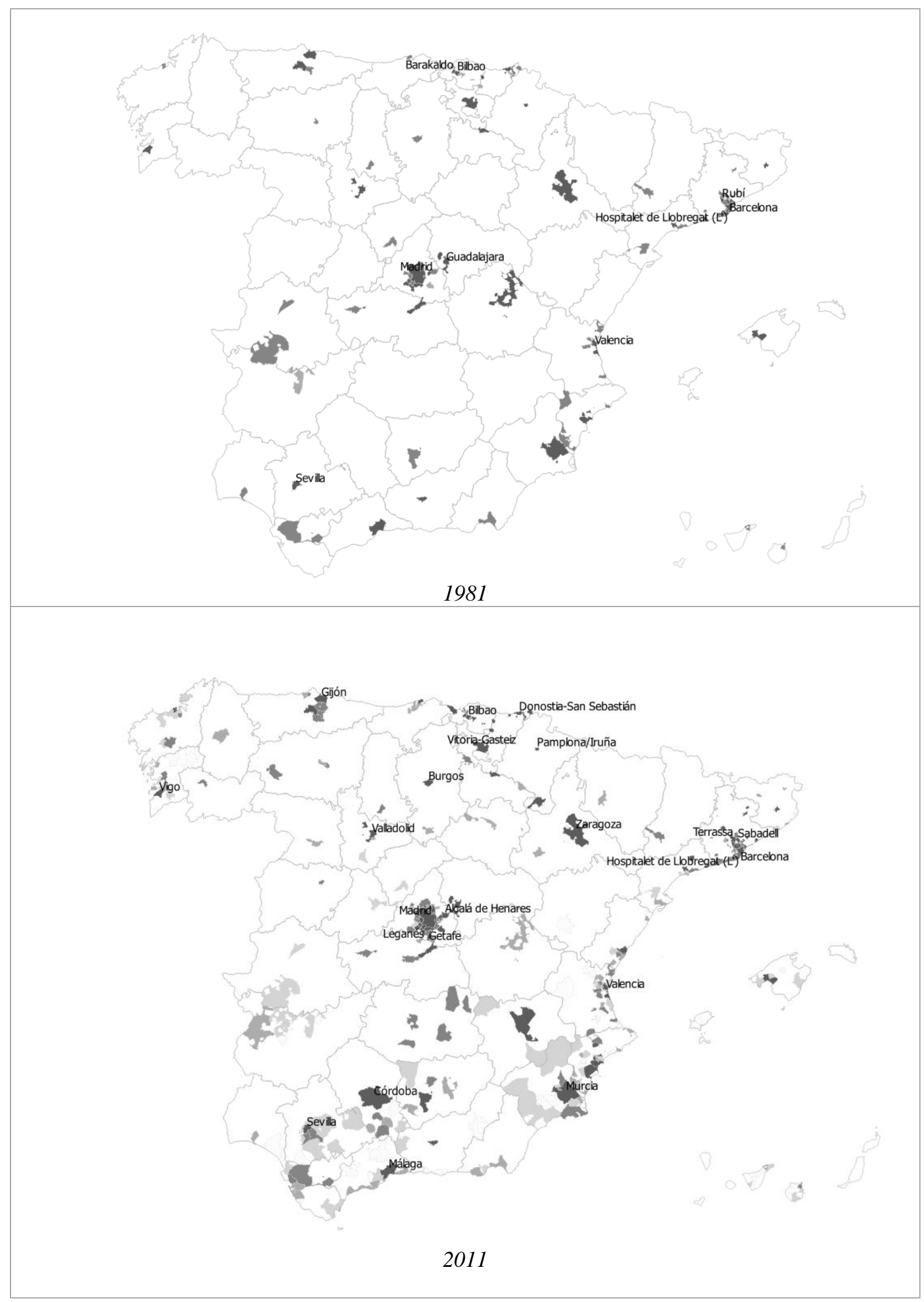

Figure A6. top $20 \%$ municipalities by employment, hi-tech (dark grey) 